\title{
New omomyoids (Euprimates, Mammalia) from the late Uintan of southern California, USA, and the question of the extinction of the Paromomyidae (Plesiadapiformes, Primates)
}

\author{
Sergi López-Torres, Mary T. Silcox, and Patricia A. Holroyd
}

\begin{abstract}
Paromomyidae has been thought to represent the longest-lived group of stem primates (plesiadapiforms), extending from the early Paleocene to late Eocene. We analyzed primate material from the late-middle Eocene of southern California that had initially been ascribed to cf. Phenacolemur shifrae. This material falls at the lowest end of the size range for the family. The Californian specimens also exhibit several dental features that are atypical for paromomyids, such as a strong paraconid on the third lower molar, and differ from early Eocene species of Phenacolemur in lacking a distally expanded distolingual basin on upper molars. This combination of traits is more typical of earlier paromomyids with more plesiomorphic morphologies (e.g., Paromomys) and as such is inconsistent with the late age of these specimens. The purported paromomyids $P h$. shifrae and Ignacius mcgrewi known in deposits of similar age are comparably tiny and share many of the characteristics found in the southern California material that distinguish them from typical early Eocene paromomyids. However, these traits are shared with some trogolemurin omomyoid euprimates that are of similar size. We argue that the material from southern California, along with $\mathrm{Ph}$. shifrae and I. mcgrewi, should be transferred to a new genus of trogolemurin omomyoid. Purported European records of paromomyids later than the earliest middle Eocene are reconsidered and found to be non-diagnostic. After the early middle Eocene, only a single tooth of a paromomyid can be confirmed, indicating that the group suffered near-extinction, possibly correlated with the Early Eocene Climatic Optimum.
\end{abstract}

Sergi López-Torres. University of Toronto Scarborough, Department of Anthropology, 1265 Military Trail, Toronto, ON, M1C 1A4, Canada. Current address: Polish Academy of Sciences, Roman Kozłowski Institute of Paleobiology, Department of Evolutionary Paleobiology, Twarda 51/55, Warsaw 00-818, Poland.slopeztorres@twarda.pan.pl

Mary T. Silcox. University of Toronto Scarborough, Department of Anthropology, 1265 Military Trail, Toronto, ON, M1C 1A4, Canada.msilcox@utsc.utoronto.ca

http://zoobank.org/5EE56527-5F98-4724-8120-18F7471BB497

López-Torres, Sergi, Silcox, Mary T., and Holroyd, Patricia A. 2018. New omomyoids (Euprimates, Mammalia) from the late Uintan of southern California, USA, and the question of the extinction of the Paromomyidae (Plesiadapiformes, Primates). Palaeontologia Electronica 21.3.37A 1-28. https://doi.org/10.26879/756

palaeo-electronica.org/content/2018/2309-new-primate-from-california

Copyright: September 2018 Society of Vertebrate Paleontology.

This is an open access article distributed under the terms of the Creative Commons Attribution License, which permits unrestricted use, distribution, and reproduction in any medium, provided the original author and source are credited.

creativecommons.org/licenses/by/4.0/creativecommons.org/licenses/by-nc-sa/4.0/ 
Patricia A. Holroyd. University of California Museum of Paleontology, 1101 Valley Life Sciences Building, Berkeley, CA, 94720, USA. pholroyd@berkeley.edu

Keywords: Omomyoidea; Trogolemurini; Paromomyidae; Eocene; new genus; new species

Submission: 21 January 2017 Acceptance: 23 August 2018

\section{INTRODUCTION}

The Paromomyidae is a family of extinct fossil mammals known from the early Paleocene (Torrejonian 1) to the late Eocene (late early Chadronian) of North America (Silcox and Gunnell, 2008; Silcox et al., 2008; Clemens and Wilson, 2009; Kinm and Tornow, 2014), the early through middle Eocene of Europe (Russell et al., 1967; Godinot, 1984; Estravís, 2000; Aumont, 2003; Hooker, 2010; Marigó et al., 2012, 2014), and the early Eocene of Asia (Tong and Wang, 1998). Paromomyids have been characterized dentally as possessing enlarged lower incisors that are inclined nearly-horizontally (i.e., sub-horizontal); $\mathrm{P}_{4}$ with a tall, pointed, broad-based protoconid; low crowned molars; and a large hypoconulid lobe on $\mathrm{M}_{3}$ (Silcox and Gunnell, 2008, Silcox et al., 2017; e.g., Phenacolemur citatus in Figure 1). Cranially, paromomyids have a long snout, small and widely spaced orbits, absence of postorbital bar, wide zygomatic arches, and inflated auditory bullae ossified from the entotympanic (Silcox and Gunnell, 2008). The postcranial skeleton of Paromomyidae suggests arborealism and vertical climbing, with strong grasping abilities similar to those of Ptilocercus, but no gliding or suspensory behaviors (Bloch and Boyer, 2007; Boyer and Bloch, 2008). Following Silcox et al. (2017), seven genera comprise the family: Paromomys, Phenacolemur, Ignacius, Elwynella, Arcius, Acidomomys, and Edworthia.

In a phylogenetic context, paromomyids were found to be closely related to Picrodontidae and the polyphyletic assemblage "Palaechthonidae", all being placed together under the superfamily Paromomyoidea (Silcox, 2001; Silcox and Gunnell, 2008; Silcox et al., 2017). Whereas, some authors have suggested that paromomyids are more closely related to dermopterans than to primates (Beard, 1989, 1990, 1993a, 1993b; Kay et al., 1990, 1992; Ni et al., 2013), other comprehensive analyses have provided compelling evidence that they are instead stem primates (Krause, 1991; Runestad and Ruff, 1995; Stafford and Thorington, 1998; Hamrick et al., 1999; Silcox, 2001; Sargis,
2002; Bloch and Boyer, 2007; Bloch et al., 2007; Boyer and Bloch, 2008).

Paromomyids are extensively distributed across North America, with records from as far north as Ellesmere Island, and as far south as Texas (Schiebout, 1974; West and Dawson, 1977; McKenna, 1980; Eberle and Greenwood, 2012). Among the furthest westward proposed North American records of the family is material described by Mason (1988, 1990) and Walsh (1991a) from Ventura and San Diego counties (California) that was referred to Phenacolemur and compared to the species $\mathrm{Ph}$. shifrae Krishtalka 1978, previously identified from late middle Eocene deposits in Wyoming assigned to the Uintan and

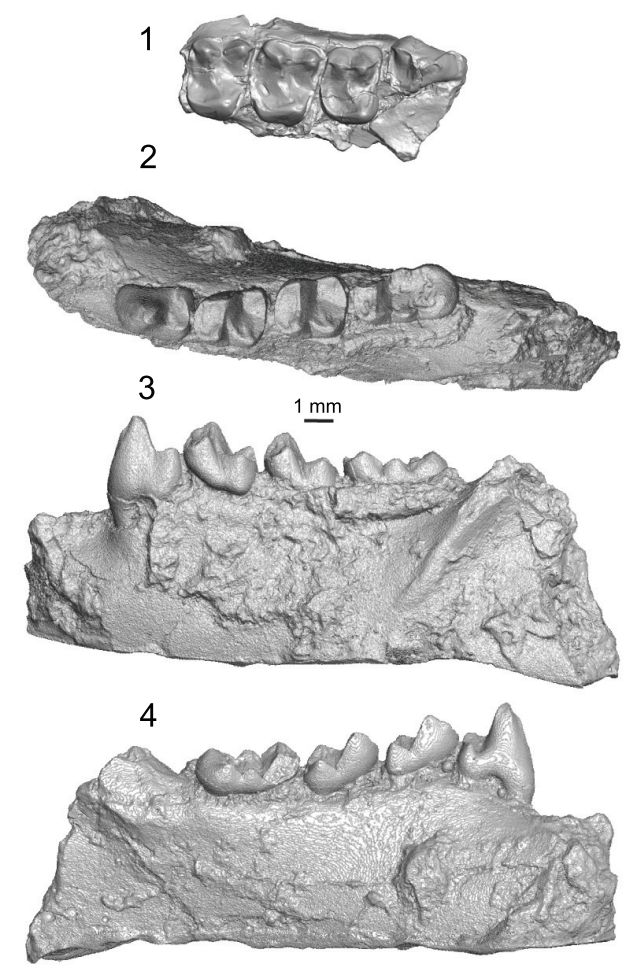

FIGURE 1. The late Wasatchian paromomyid Phenacolemur citatus. 1: USGS 6573 (original fossil), right maxilla with $\mathrm{P}^{3}-\mathrm{M}^{2}$. 2-4: USGS 21712 (cast), left dentary with $\mathrm{P}_{4}-\mathrm{M}_{3}$ in occlusal (2), buccal (3), and lingual (4) views. 
Duchesnean North American Land Mammals Ages (see Robinson et al., 2004).

However, it is worth noting that there have been some instances of confusion in late occurring samples between paromomyids and another group of early Cenozoic primates, the Omomyoidea. Omomyoids are euprimates (i.e., primates of modern aspect, more closely related to living primates than to plesiadapiforms) that first appear near the Paleocene-Eocene boundary in North America, Europe, and Asia (Ni et al., 2004; Smith et al., 2006; Rose et al., 2011). During the early Paleogene, paromomyid plesiadapiforms and omomyoid primates both diversified at small body sizes, and selected subsets of each clade exhibit very similar dental features (i.e., expanded distolingual basins in upper molars, enlarged sub-horizontal first lower incisors, large hypoconulid lobes on $\mathrm{M}_{3}$ ) and may have had similar ecological roles. A late middle Eocene primate from Saskatchewan originally described as a paromomyid (Storer, 1990) was found to be a trogolemurin omomyid, Trogolemur leonardi (Beard et al., 1992). Here we follow a restricted concept of Trogolemurini (i.e., only containing two genera: Trogolemur and Sphacorhysis) as defined by Gunnell and Rose (2002). As so defined, Trogolemurini is a tribe of anaptomorphine omomyoids known from the late early Eocene (late Wasatchian) of Wyoming (Williams and Covert, 1994) and the middle Eocene (Bridgerian to Duchesnean) of Wyoming (Matthew, 1909; Beard et al., 1992; Gunnell, 1995), Nevada (Emry, 1990), and Saskatchewan (Storer, 1990). Trogolemurins are among the smallest known omomyoids. As is true of paromomyid plesiadapiforms, trogolemurins are characterized by having enlarged sub-horizontal central incisors, although they sometimes retain a small $\mathrm{I}_{2}$. Consequently, they have an anteriorly deep mandible to accommodate this enlarged tooth, like paromomyids do. They retain a small canine and a $\mathrm{P}_{3}$, unlike most paromomyids. The teeth between $\mathrm{I}_{1}$ and $\mathrm{P}_{4}$ are very close together and are inclined mesially. The trogolemurin $\mathrm{P}_{4}$ is reduced in size, with a very small to absent metaconid, and the $M_{3}$ has a short and broad hypoconulid lobe (Gunnell and Rose, 2002; Figure 2), making these teeth quite different from those of most paromomyids, in which the $\mathrm{P}_{4}$ is expanded and the $M_{3}$ hypoconulid more enlarged. The $\mathrm{P}^{4}$ paracone is much taller than its very small protocone (Gunnell, 1995). Upper molars of trogolemurins have prominent protocones, narrow postprotocingula, and weak conules
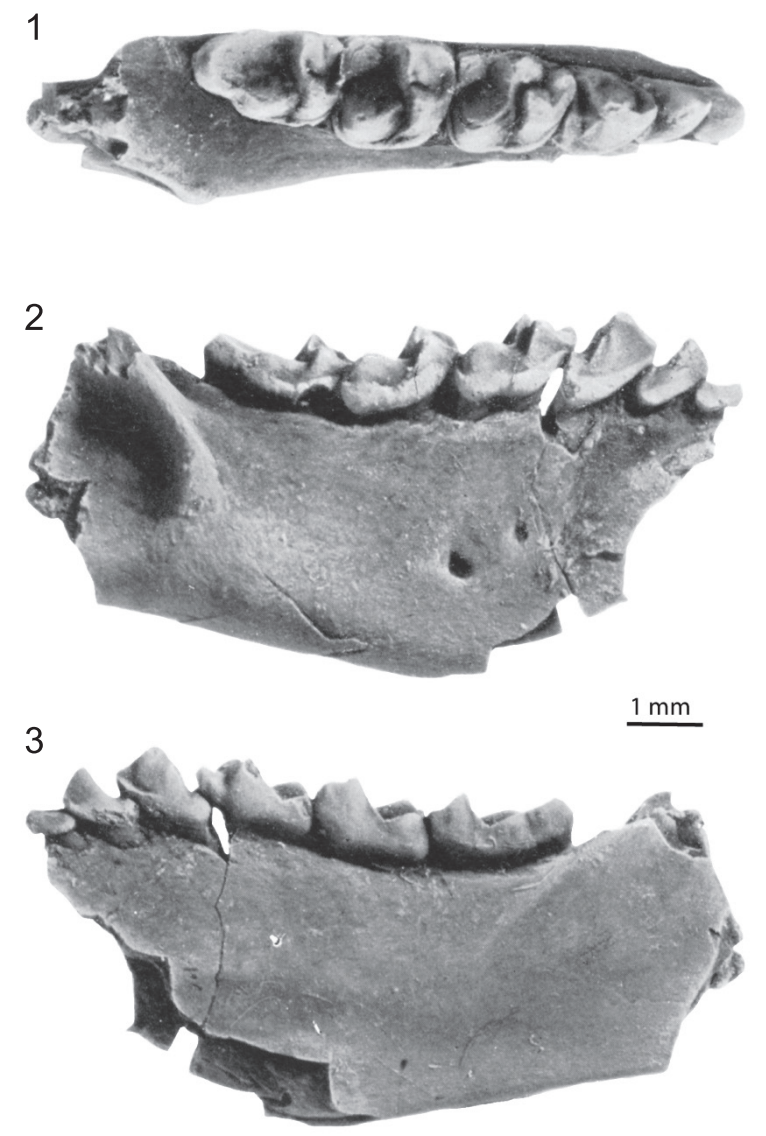

FIGURE 2. Holotype of Trogolemur myodes, AMNH 12599 (Matthew, 1909: plate LII, figure 5). Right dentary with $\mathrm{P}_{2}-\mathrm{M}_{3}$. 1: occlusal view; 2 : buccal view; 3: lingual view.

(Gunnell and Rose, 2002), making them more paromomyid-like and generating potential confusion when isolated teeth are found (e.g., Storer, 1990). No trogolemurin postcranial material has been reported.

The first attempt to place a trogolemurin in a cladistic context was done by Williams (1994), and she found that Tr. myodes was most closely related to Anemorhysis. That was also supported by Williams and Covert (1994). Gunnell (1995) depicted a Tetonoides-Arapahovius clade as sister group to Trogolemurini. Although this differs from the results of Williams (1994) and Williams and Covert (1994), this conclusion would still ally trogolemurins with North American anaptomorphins. Later, larger and more comprehensive analyses suggested that $T r$. myodes is closely related to the European microchoerines Microchoerus, Necrolemur, Nannopithex, and Pseudoloris (Ross et al., 1998; Ni et al., 2004). However, the analysis by Tornow (2008) 
provided support for the previous idea of Trogolemur myodes grouping with Anemorhysis. There are, therefore, two conflicting interpretations of trogolemurin relationships: they are either related to North American anaptomorphins (Williams, 1994; Williams and Covert, 1994; Gunnell, 1995; Tornow, 2008 ) or to European microchoerines (Ross et al., 1998; Ni et al., 2004).

In light of the past confusion between specimens of paromomyids and trogolemurins, we formally describe and re-examine the affinities of the southern Californian primate specimens that had been attributed to cf. Ph. shifrae, and of similarly aged material from the Uintan and Duchesnean of Wyoming (Robinson, 1968; Krishtalka, 1978). Because these represent some of the youngest reported paromomyids, our study also prompts reconsideration of the larger question of the temporal distribution of paromomyids and, more generally, of the ecological and environmental factors that might have been driving these patterns.

\section{Institutional Abbreviations}

AMNH-American Museum of Natural History, New York City, NY, USA; CM-Carnegie Museum of Natural History, Pittsburgh, PA, USA; LACM-Natural History Museum of Los Angeles County, Los Angeles, CA, USA; LACM (CIT)-California Institute of Technology collections, now held by LACM; RSMRoyal Saskatchewan Museum, Regina, SK, Canada; SDSNH-San Diego Society of Natural History, San Diego, CA, USA; SMNH-Saskatchewan Museum of Natural History (now RSM); UCM-University of Colorado Museum, Boulder, CO, USA; UCMP-University of California Museum of Paleontology, Berkeley, CA, USA; UM-University of Michigan, Ann Arbor, MI, USA; USNM-United States National Museum, Washington, DC, USA; YPM VP-Division of Vertebrate Paleontology, Yale Peabody Museum, New Haven, CT, USA.

\section{Historical and Geological Context of Southern Californian Localities}

The history of collecting fossil mammals from the Eocene of southern California dates back to the work of Stock (1934a, 1934b, 1935, 1936, 1938, 1948) and Wilson (1935a, 1935b, 1940a, 1940b), when they described the first Eocene insectivores, marsupials, and rodents of the area. Later work recognized several local faunas (Lindsay, 1968; Golz, 1976; Golz and Lillegraven, 1977; Lillegraven, 1979, 1980; Eaton, 1982; Kelly, 1990; Mason, 1988, 1990; Kelly et al., 1991; Theodor, 1999; Wesley and Flynn, 2003; Ludtke and Proth- ero, 2004; Colbert, 2006; Tomiya, 2013). Of particular note in the current context are the extensive contributions by Walsh (Walsh and Estes, 1985; Walsh, 1987, 1991a, 1991b, 1996, 1997, 1998, 2000; Walsh and Gutzler, 1999), who amassed impressive collections that currently reside at the San Diego Natural History Museum, much of which remains unpublished. However, the primate material from southern California is remarkably scarce. The current study deals specifically with material originally collected by Mason $(1988,1990)$ and Walsh (1991a) from Ventura and San Diego Counties (California). In the Eocene, fossil localities from these two Californian counties would have had similar latitudinal positions to today but would have lain approximately 2 degrees of latitude to the south and 3 degrees of longitude to the east (see paleoposition reconstruction in Figure 3) due to movement along faults. The western US coastline would have been approximately 10 degrees to the east, having since moved west due to post-Eocene continental and sea-floor spreading movements (see McQuarrie and Wernicke, 2005 for a recent synthesis).

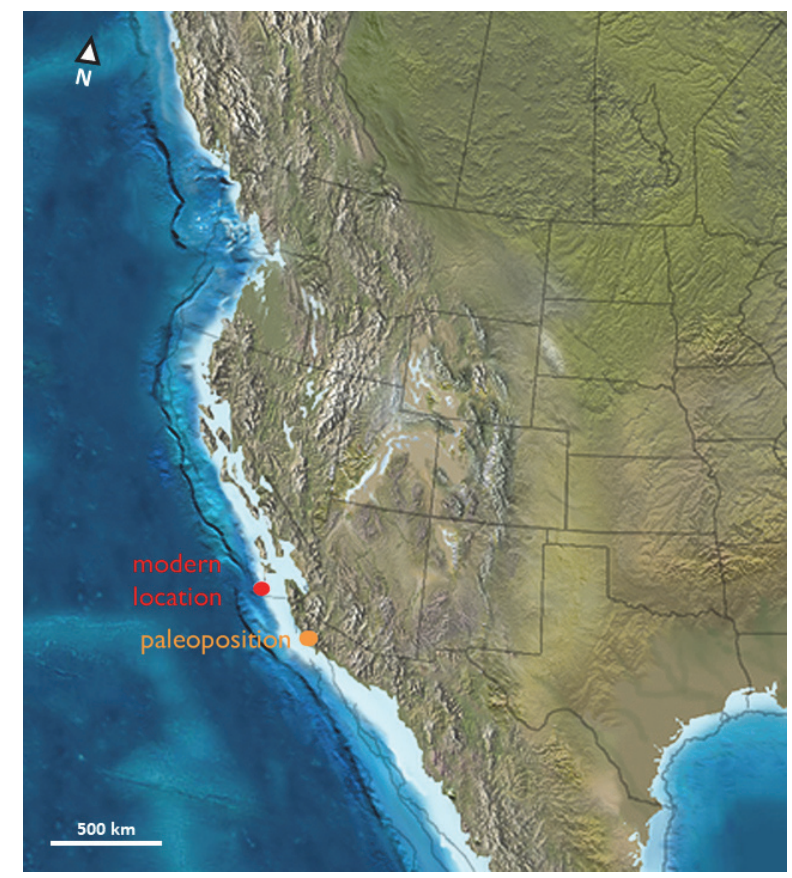

FIGURE 3. Reconstruction of western North America from 40 million years ago. Orange dot indicates the paleoposition of the sites discussed in this paper, whereas the red dot indicates the current relative position of the sites. The map is reproduced with R. Blakey's permission (Colorado Plateau Geosystems, Inc.). 
Here we examine specimens from five localities (SDSNH localities 3276, 3426, 4081, 4082, and LACM (CIT) 180), which occur in river-deposited (alluvial) terrestrial sediments. These sediments formed on a coastal plain that would have featured a mix of lagoonal, estuarine, and riverine environments. Westward, the area grades into shelf sediments deposited in forearc basins created by the subduction of the Pacific plate under the North American plate (e.g., Link et al., 1979; Howard and Lowry, 1995; Abbott, 1999; Berry, 1999). The shoreline was never very far to the west, with uplands and mountains with mixed coniferous forests to the east (Frederiksen, 1991). In the Eocene, the climate would have been tropical to subtropical, although researchers differ in their interpretations of forest structure, seasonality, and amount of precipitation in the various formations that have produced mammalian fossils, as discussed below.

The geologic history of San Diego and Ventura counties in southern California is complex, having been affected by significant movement along the San Andreas and related faults, and the literature can be confusing, as some formation names as well as age interpretations have changed. Here we summarize the geology and collecting history of five localities that have produced primate fossil specimens (SDSNH localities 3276, 3426, 4081, 4082, and LACM (CIT) 180), provide data relevant to determining their age and paleoenvironment, and refer the reader to other reviews that can provide more in-depth background on alternate interpretations or older data.

Mission Valley Formation, southwest San Diego County (SDSNH localities 3426 and 4020). SDSNH locality 3426 , Collwood South, is a $2 \mathrm{~m}$ thick light brown sandy mudstone bed that occurs within the restricted concept of the Mission Valley Formation (see discussion in Walsh et al., 1996). According to the SDSNH records, $\sim 1150 \mathrm{~kg}$ of sediment were processed for microvertebrates. The fauna of SDSNH locality 3426 is united with that of other nearby localities as the Cloud 9 local fauna, and is considered late Uintan in age (Walsh, 1991a, 1996).

Walsh et al. (1996) reported a single-crystal ${ }^{40} \mathrm{Ar} / 39 \mathrm{Ar}$ age of $42.83 \pm 0.24 \mathrm{Ma}$ from a pink bentonite of normal magnetism in the Mission Valley Formation. Measured sections of the Mission Valley Formation in San Diego span both normal and reversed polarity intervals (Bottjer et al., 1991; Walsh et al., 1996). Bottjer et al. (1991) interpreted it as Chron $18 \mathrm{r}$ and thought that Chron 19r was likely missing in the local area (or represented by an unsampled formation), but additional sampling and correlation of local sections led to interpretation as Chrons 20n and 19r (Walsh et al., 1996; Prothero, 2001a), an assignment consistent with the radiometric age.

Peterson and Abbott (1979) reviewed the geologic evidence for immaturity in the development of clay minerals combined with the common development of caliche horizons in the Mission Valley Formation and the slightly older Friars Formation to suggest that the climate was warm $\left(18-20^{\circ} \mathrm{C}\right.$ mean annual temperature) with low average annual rainfall (ca. $63 \mathrm{~cm}^{3}$ ). Additional lines of evidence include pollen documenting the presence of palms and a diversity of paratropical to tropical tree taxa (Frederiksen, 1991). Additionally, an analysis of the mammalian diversity (Novacek and Lillegraven, 1979) suggested similarities to complex, modern eastern African habitats with a mix of riparian habitats grading into gallery forests and/or savanna, a slightly wider range of warm temperatures (20-22 ${ }^{\circ} \mathrm{C}$ ), and possible annual rainfall of $50-100 \mathrm{~cm}^{3}$. Based on land snails from Mission Valley and Friars formations in San Diego, and locality LACM (CIT) 180 in the Sespe Formation, Roth (1988) inferred the presence of dry tropical forest throughout the region.

SDSNH locality 4020 (SR 125 North [Unit I] Grossmont Summit) has previously been assigned to the late Uintan Cloud 9 local fauna (Walsh, 1996), and Penkrot and Zack (2016) have reported on erinaceomorph lipotyphlan tarsals from this site. SDSNH 4020 is in the Mission Valley Formation in the city of El Cajon. Fossils occurred in a $\sim 0.6-1.5$ $\mathrm{m}$ thick massive, brown, medium-grained, silty sandstone with some calcareous concretions from which thousands of fossils, including articulated skeletons, were recovered. The presence of pulmonate (terrestrial) snails led the site to be informally called "the snail beds". Approximately 3265 $\mathrm{kg}$ of sediment were screenwashed.

Member C of Santiago Formation, northwest San Diego County (SDSNH localities 3276, 4081, 4082, and 4925). The only paleoenvironmental interpretation based exclusively on specimens from the Santiago Formation is a study of land snails from SDSNH locality 3276 (Jeff's Discovery, Santiago Formation, Member C, Oceanside, San Diego County, CA), which found the distribution of shell sizes and shapes to be consistent with interpretations of subtropical to tropical conditions and paleotemperatures in excess of 25 ${ }^{\circ} \mathrm{C}$ (Roth, 1991). 
Prothero (2001b) found the strata of Member C of the Santiago Formation at the Jeff's Discovery locality to be entirely reversed and suggested it correlated with Chron C19r (42.5 Ma-41.5 Ma), because correlative rocks with similar fossils from the upper Mission Valley Formation in southern San Diego County probably also correlate with this magnetic chron (Walsh et al., 1996).

SDSNH localities 4081 and 4082 (Emerald Ridge Sites 1 and 2) and 4925 (Kelly Ranch Core Mammal and Coprolite Site) have not previously been reported in the literature or assigned to a local fauna. All are from Member C of the Santiago Formation and were found during the course of construction projects for the named housing developments in the city of Carlsbad. SDNSH 4081 (Emerald Ridge Site 1) is a 0.3-0.6 m thick weaklycemented sandstone channel with mudstone and siltstone clasts. A total of $\sim 1995 \mathrm{~kg}$ of matrix were collected and washed through 24 mesh $(0.7 \mathrm{~mm})$ screens (SDSNH records). SDSNH 4082 (Emerald Ridge Site 2) is lithologically similar to SDSNH 4081 and may be the same bed but is separated from it by faulting. A total of $\sim 1815 \mathrm{~kg}$ of matrix were collected and processed (SDSNH records). SDSNH 4925 is a $\sim 0.6 \mathrm{~m}$ thick, gray-green, fine grained sandy siltstone from which approximately $\sim 2900 \mathrm{~kg}$ of sediment were hand quarried and screenwashed (SDNSH records).

Sespe Formation, Simi Valley, Ventura County (LACM (CIT) 180). Kelly (1990) placed the taxa from the Dry Canyon localities, including LACM (CIT) 180, as part of the Tapo Canyon local fauna, where it co-occurs with the omomyoid Dyseolemur pacificus in the late Uintan part of the middle member of the Sespe Formation, the oldest part of the middle Eocene sequences in the Simi Valley area. Locality LACM (CIT) 180 is situated $389 \mathrm{~m}$ above the base of the Sespe Formation and was assigned a late Uintan age (Mason, 1990).

Prothero et al. (1996) placed these rocks in the lower half of Chron 18r, but Walsh (1996) expressed skepticism about this younger age assignment. Based on biostratigraphy, Robinson et al. (2004) assigned the Tapo Canyon local fauna to Ui3. Most recently, Kelly et al. (2012) proposed a correlation to Chron 19r based on a new interpretation of the correlation between the southern California middle Eocene record and that of the Uinta and Duchesne River formations in Utah, and this correlation was also found to be most consistent with the ranges of carnivoramorphs (Tomiya, 2013).
As inferred for the Mission Valley Formation, Roth (1988) used the record of land snails and concluded that dry tropical forest was present in the Sespe Formation.

In sum, biostratigraphic, magnetostratigraphic, and radiometric evidence most strongly suggest that all these southern Californian sites are similar in age, likely assignable to the Ui3 subzone of the Uintan North American Land Mammal Age, fall within Chron 19r, i.e., are 42.301 Ma41.390 $\mathrm{Ma}$ in age (Ogg, 2012), and are within the latest part of the Lutetian Standard Stage. Alternative interpretations that suggest the Ventura County localities are younger, or that all the sites are older (see Tomiya, 2013 for a review), are not well supported.

\section{SYSTEMATIC PALEONTOLOGY}

Order PRIMATES Linnaeus, 1758

Suborder HAPLORHINI Pocock, 1918

Superfamily OMOMYOIDEA Trouessart, 1879

Family OMOMYIDAE Trouessart, 1879

Subfamily ANAPTOMORPHINAE Cope, 1883

Tribe TROGOLEMURINI Szalay, 1976

Genus WALSHINA gen. nov.

Figures 4.1-4.4, 5.1-5.11, 6.1-6.19

zoobank.org/5F051939-CD72-4EBC-8BBC-3E6B637DC806

1968 Phenacolemur (Matthew, 1915); Robinson, p. 324

1976 Ignacius (Matthew and Granger, 1921); Bown and Rose, p. 112 (in part)

1978 Phenacolemur (Matthew, 1915); Krishtalka, p. 338, fig. 2-4

1990 Phenacolemur (Matthew, 1915); Mason, p. 2, fig. 2

1991a cf. Phenacolemur (Matthew, 1915); Walsh, p. 166, table 1

1996 Phenacolemur (Matthew, 1915); Walsh, p. 85, table 2

Type species. Walshina esmaraldensis gen. et sp. nov.

Included species. Type species, Walshina mcgrewi comb. nov. (= I. mcgrewi Robinson, 1968), and Walshina shifrae comb. nov. (=Ph. shifrae Krishtalka, 1978).

Distribution. Uintan and Duchesnean of Wyoming, and Uintan of California.

Etymology. In memory of Stephen L. Walsh of the San Diego Museum of Natural History, in recognition of his work on the San Diego County faunas.

Diagnosis. Paracristid of $\mathrm{M}_{1}$ relatively long as in Trogolemur and Sphacorhysis, but paraconid less clearly distinct from the paracristid. Differs from 


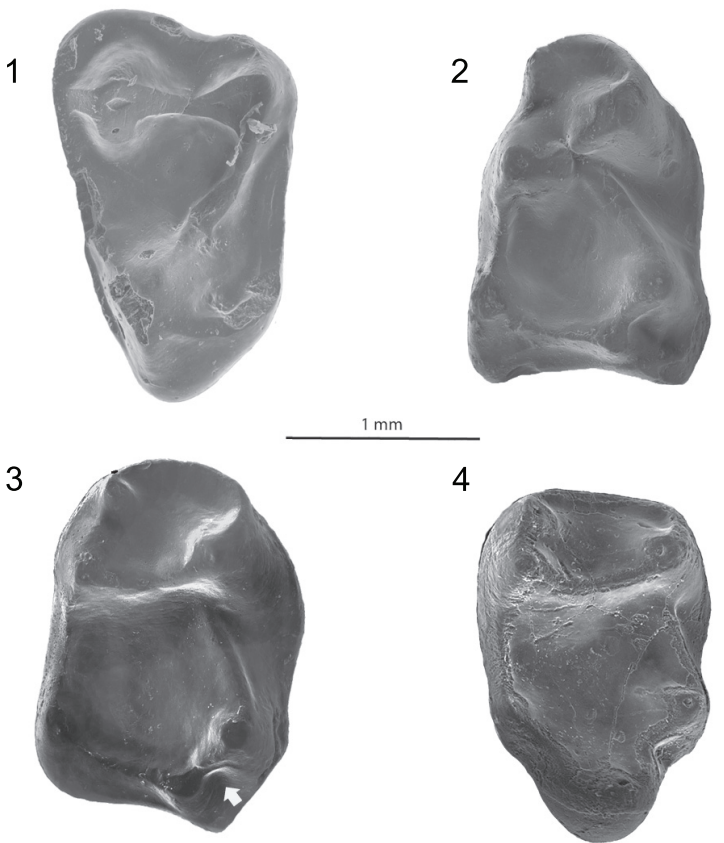

FIGURE 4. Environmental SEM images of four teeth of Walshina esmaraldensis gen. et sp. nov. 1: left $\mathrm{M}^{3}$, SDSNH 76276; 2: right $M_{1}$, SDSNH 76337; 3: right $M_{2}$, SDSNH 76338; 4: right $\mathrm{M}_{3}$, SDSNH 72583. All teeth are in occlusal view. Arrow indicates the location of the fovea.

Sphacorhysis (but not Trogolemur) in having lower molar talonid basins that are relatively deep with smooth enamel. Differs from Trogolemur (but not Sphacorhysis) in that the cristid obliqua of $\mathrm{M}_{1}$ contacts the postvallid distal to the protoconid rather than between the protoconid and metaconid. Unlike the other trogolemurins, $M_{1}$ and $M_{2}$ of Walshina gen. nov. have strong hypoconulids with distinct foveae located below and buccal to the hypoconulid. As in Sphacorhysis, the distal aspect of $\mathrm{M}_{1}$ and $\mathrm{M}_{2}$ is convex, whereas in Trogolemur it is concave. $\mathrm{M}_{3}$ hypoconulid narrower than in other trogolemurins. $\mathrm{M}_{3}$ trigonid significantly taller than in Sphacorhysis (but not Trogolemur). Like Sphacorhysis, lower molar entocristids form a rounded contour (i.e., forming a U-shaped entocristid) in lingual view, in contrast to the V-shaped entocristid in Trogolemur. Further differs from Trogolemur and Sphacorhysis in having much weaker buccal cingulids. Notably stronger precingulum on $\mathrm{M}^{2}$ than in Trogolemur. Protocone lingual expansion on the upper molars not as pronounced as in Trogolemur. Compared to Trogolemur, mesial aspect of $\mathrm{M}^{3}$ straighter, and the lingual border of that tooth much shorter mesiodistally relative to its buccal border.
Discussion. All trogolemurins share a distally expanded distolingual basin of the upper molars (particularly marked in W. mcgrewi comb. nov.), which is quite similar to that observed in paromomyid plesiadapiforms. This similarity is likely one reason why some members of Walshina gen. nov. have previously been considered paromomyids. However, in other ways the morphology of trogolemurins is inconsistent with that of paromomyids, including the presence of paraconids on $\mathrm{M}_{3}$. Walshina gen. nov. remains quite poorly known, with the only record being isolated upper and lower molars. One likely reason for this limited record is that the genus includes the smallest North American omomyoids (see below).

Walshina esmaraldensis gen. et sp. nov.

Figures 4.1-4.4, 5.2, 5.5, 6.1-6.19 zoobank.org/9E482E98-74DA-4ECC-9BE1-6AA10C07D41F

Phenacolemur cf. shifrae Mason, 1990; Walsh, 1996.

Holotype. LACM 40198, left M1.

Hypodigm. M2: SDSNH 42268, 62850, 87336, 87337; $M^{3}$ : SDSNH 76267; $\mathrm{M}_{1}$ : SDSNH 76337, 87331; $M_{2}$ : SDSNH 76338, 87332, 87333; $M_{3}$ : SDSNH 72583, 76266, 76339, 87334, 87335.

Type locality. LACM (CIT) 180, north of Simi Valley, Ventura County, California, USA. Late Uintan (Ui3).

Etymology. In reference to the localities of Emerald Ridge (Vulgar Latin: esmaraldus).

Diagnosis. Intermediate in size between $W$. mcgrewi comb. nov. and $W$. shifrae comb. nov. Differs from $W$. mcgrewi comb. nov. in having a hypoconulid closer to the hypoconid than to the entoconid on $\mathrm{M}_{2}$, similar to $W$. shifrae comb. nov. Very large hypoconulids on $M_{1}$ and $M_{2}$, whereas they are weakly developed in $W$. mcgrewi comb. nov. and $W$. shifrae comb. nov. $\mathrm{M}_{2}$ trigonid and talonid of similar width, whereas $W$. mcgrewi comb. nov. and $W$. shifrae comb. nov. have significantly wider $\mathrm{M}_{2}$ talonid bases relative to the trigonid base. $\mathrm{M}_{3}$ with larger paraconid and taller metaconid relative to the protoconid than in $W$. shifrae comb. nov. Hypoconulid lobe of $M_{3}$ not expanded as far distally from the apex of the hypoconulid as in $W$. shifrae comb. nov. Differs from W. mcgrewi comb. nov. (but not $W$. shifrae comb. nov.) in having upper molars with smaller distolingual basins. In mesial view, $\mathrm{M}^{1}$ with a less clearly delineated preprotocrista, like $W$. mogrewi comb. nov. $\mathrm{M}^{2}$ with a much more lingually expanded protocone lobe than 
1

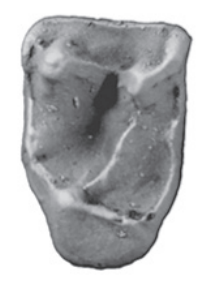

4

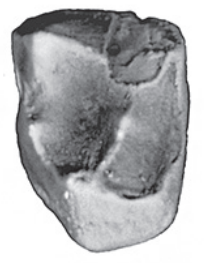

2

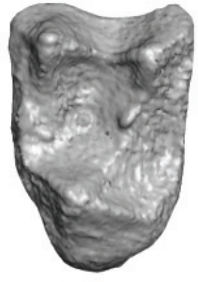

5

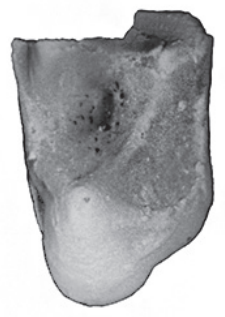

3

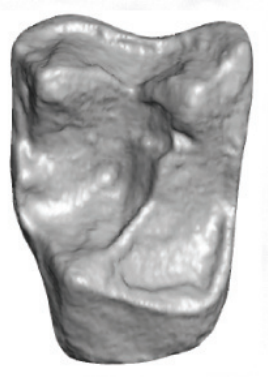

6

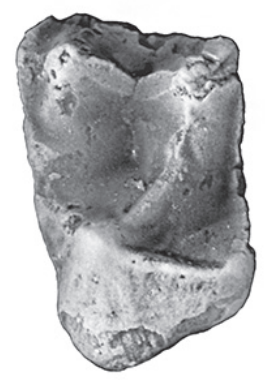

$1 \mathrm{~mm}$

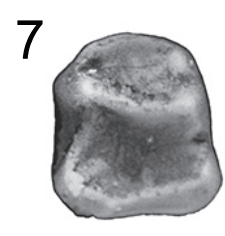

10
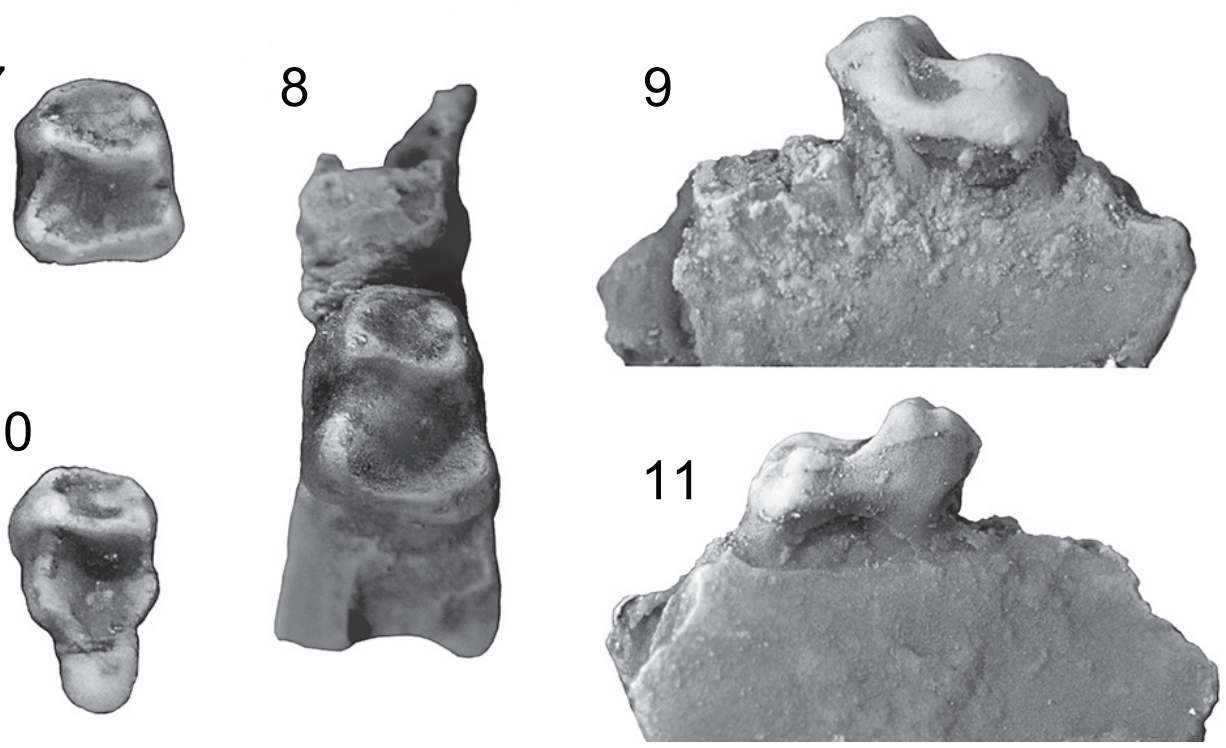

FIGURE 5. Photographs taken with digital camera (1, 4-11) and Micro-CT scan reconstructions generated using Avizo 7 (2, 3). Walshina shifrae comb. nov. $(1,4,7,10)-1$ : right $\mathrm{M}^{1}$, CM 15797 (holotype; mirrored), in occlusal view; 4: left $M^{2}$, CM 15103, in occlusal view; 7: left $\mathrm{M}_{2}, \mathrm{CM} 21637$, in occlusal view; 10: left $\mathrm{M}_{3}$; CM 15726, in occlusal view. Walshina esmaraldensis gen. et sp. nov. $(2,5)$ - 2: left M11, LACM 40198 (holotype), in occlusal view; 5: left M2, SDSNH 62850, in occlusal view. Walshina mcgrewi comb. nov. (3, 6, 8, 9, 11) - 3: left M1 , CM 15635 (holotype), in occlusal view; 6 : left $\mathrm{M}^{2}$, CM15794, in occlusal view; 8, 9, 11: left mandibular fragment with $\mathrm{M}_{2}$, CM 29005, in occlusal (8), buccal (9), and lingual (11) views.

in W. shifrae comb. nov. (but not in W. mcgrewi comb. nov.).

\section{DESCRIPTION AND COMPARISONS}

The only known $\mathrm{M}^{1}$ of $W$. esmaraldensis gen. et sp. nov. comes from LACM (CIT) 180 from Simi Valley, Ventura County, California, and was described by Mason (1990). It differs from all other 
1

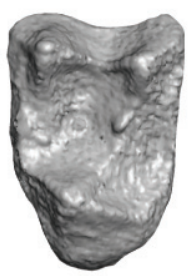

5

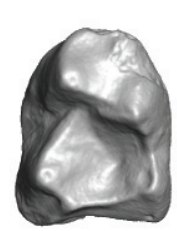

9

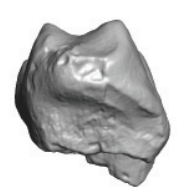

13

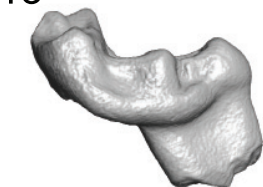

17

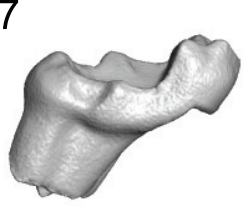

2

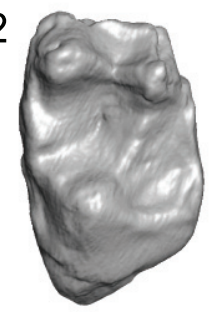

6
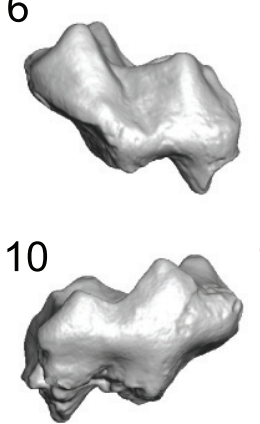

14

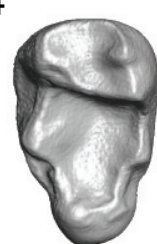

18

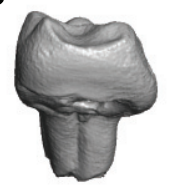

3

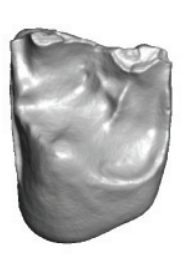

7

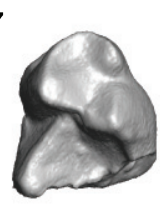

11

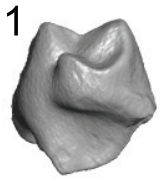

15

19
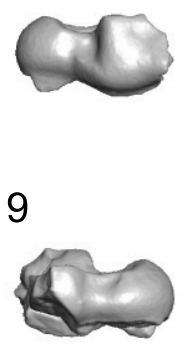

4

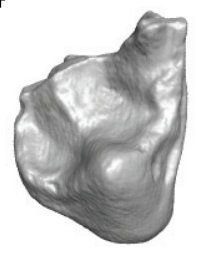

8

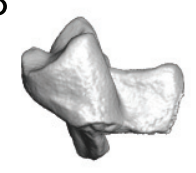

12

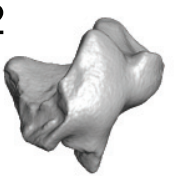

16

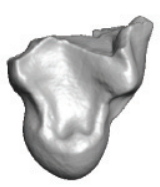

$1 \mathrm{~mm}$

FIGURE 6. Micro-CT scan reconstructions of specimens of Walshina esmaraldensis gen. et sp. nov. generated using Avizo 7: 1: left M11, LACM 40198 (holotype), in occlusal view; 2: left M², SDSNH 87336, in occlusal view; 3: lingual fragment of a left $\mathrm{M}^{2}$, SDSNH 87337, in occlusal view; 4: lingual fragment of a right $\mathrm{M}^{2}$, SDSNH 42268, in occlusal view; 5, 6, 9, 10: left $\mathrm{M}_{2}$, SDSNH 87332, in occlusal (5), buccal (6), mesial (9) and lingual (10) views; 7, 8, 11, 12: mesial fragment of a left $\mathrm{M}_{1}$, SDSNH 87331, in occlusal (7), buccal (8), mesial (11) and lingual (12) views; 13, 14, 17, 18: left $\mathrm{M}_{3}$, SDSNH 87334, in buccal (13), occlusal (14), lingual (17) and mesial (18) views; 15, 16, 19: distal fragment of a right $\mathrm{M}_{3}$, SDSNH 87335, in buccal (15), occlusal (16) and lingual (19) views.

upper molars of $W$. esmaraldensis gen. et sp. nov. in having a less expanded distolingual basin, and a metastylar lobe that extends buccally to a similar degree as the parastylar lobe, which is a typical difference between $\mathrm{M}^{1} \mathrm{~s}$ and $\mathrm{M}^{2} \mathrm{~s}$ in many early primate taxa. Mason (1990) attributed LACM 40198 to Ph. sp. cf. Ph. shifrae, and stated that the sole diagnostic character to differentiate $W$. mcgrewi comb. nov. from $W$. shifrae comb. nov. was size. Although size is a useful diagnostic character in Walshina gen. nov., there are a number of other distinguishing features (i.e., position of the hypoconulid of $M_{2}$, size of the hypoconulid on $M_{1-2}$, trigo- nid-talonid width proportion on $\mathrm{M}_{2}$, size of paraconid on $\mathrm{M}_{3}$, height of metaconid on $\mathrm{M}_{3}$, size of hypoconulid lobe on $\mathrm{M}_{3}$, expansion of distolingual basins on upper molars, expression of the preprotocrista on $\mathrm{M}^{1}$, expansion of the protocone lobe on $\mathrm{M}^{2}$ ) that can be used to differentiate among the species. Nonetheless, Mason (1990) provides an adequate description of this tooth.

Both specimens of $\mathrm{M}^{2}$ have an oblique buccal border due to a reduced metacone relative to the paracone and a more expanded distolingual basin than $\mathrm{M}^{1}$. On the $\mathrm{M}^{2}$, the postprotocingulum runs 
straight mesiodistally, creating a sharper angle with the postcingulum than seen on the $M^{1}$, where the postprotocingulum and postcingulum are more buccally oblique. The outline of $\mathrm{M}^{2}$ is rectangular rather than squared, with a longer buccolingual distance. The distolingual basin is deep, with a straight distal aspect of the tooth, instead of concave. The paracone and metacone are well separated. The trigon basin is also deep. The parastylar region is damaged in all $\mathrm{M}^{2}$ specimens, so it is impossible to determine the presence of a parastyle or the true degree of expansion of the parastylar region. There is no metastyle. Only one conule is present, a minute paraconule, with an associated preparaconule crista, but no postparaconule crista. The paraconule is closer to the paracone than to the protocone. The protocone is slightly skewed mesiolingually. The protocone lobe of $W$. esmaraldensis gen. et sp. nov. is very lingually expanded; more so than in $W$. shifrae comb. nov. but less so than in Trogolemur. However, none of the other trogolemurins have a distolingual basin as expanded as that of the $\mathrm{M}^{2}$ of $W$. mcgrewi comb. nov., which is so expanded that the postcingulum curves distally beyond the plane of the metacone in the lingual aspect of the tooth. In contrast, the distolingual basin in $W$. esmaraldensis gen. et sp. nov. does not extend further distally than the metacone.

The only $\mathrm{M}^{3}$ known for the genus Walshina gen. nov. belongs to $W$. esmaraldensis gen. et $\mathrm{sp}$. nov. The paracone and metacone of this tooth (SDSNH 76267) are very worn. The metacone is significantly smaller than the paracone. No conules are present. There is a strong postprotocrista, but the preprotocrista is completely absent. The lingual half of the $\mathrm{M}^{3}$ is markedly shorter mesiodistally than the buccal half, so that the tooth has a quite triangular outline.

On the $M_{1}$, the breadth of the talonid near the apices of the cusps is greater than the breadth of the trigonid. The paraconid is present on a welldeveloped paracristid that extends well beyond the paraconid and metaconid, making the front of the tooth very long and narrow. On the $\mathrm{M}_{1}$, the paracristid can be as tall as the tip of the paraconid, making that cusp poorly defined; whereas on the $M_{2}$, the paracristid is lower and the paraconid is more distinct from this crest. On the $M_{1}$, the metaconid is distally displaced relative to the protoconid and the postvallid is stepped (sensu Silcox, 2001). The crests on the lower molars are all well delineated, in association with the teeth being fairly high crowned (much more so, for example, than in Sphacorhysis). On both $\mathrm{M}_{1}$ and $\mathrm{M}_{2}$, the distal slopes of the entoconid and the hypoconid are expanded beyond the apices of these cusps, giving the distal border of the tooth a convex aspect. There is a fovea on the distal aspect of the tooth between the hypoconulid and the hypoconid. The hypoconulid is well defined and shifted far buccally, being close to the hypoconid.

The $\mathrm{M}_{3}$ paraconid is large. The trigonid has a steep distal aspect of the metaconid. The hypoconulid is enlarged into a lobe. The $\mathrm{M}_{3}$ is narrower at the hypoconulid than at the level of the tip of the hypoconid and the tip of the entoconid (i.e., low hypoconulid lobe/mid tooth ratio). The only other known $\mathrm{M}_{3}$ of Walshina gen. nov. belongs to $W$. shifrae comb. nov. Whereas there is a clear difference in size, the two species also differ in the relative proportions of the hypoconulid lobe. The buccolingual width of the hypoconulid lobe in $W$. shifrae comb. nov. is smaller than in $W$. esmaraldensis gen. et sp. nov. relative to the distance between the hypoconid and the entoconid, making this part of the tooth appear narrower. The hypoconulid lobe of $W$. shifrae comb. nov. also has a longer distal slope than in $W$. esmaraldensis gen. et sp. nov., so that the hypoconulid lobe extends further from the tip of the hypoconulid.

Body mass estimates using equations by Gingerich et al. (1982) and the prosimian equation by Conroy (1987) are shown for all species of trogolemurins in Table 1. Measurements used for calculating body mass estimates are shown in Appendix 1. The equation by Conroy (1987) would be expected to provide more relevant estimates, because it is based on the subset of living primates most likely to be comparable to the fossil taxa. However, he only provided an equation for the $M_{1}$, which is problematic in this case because that tooth locus is unknown in several species of trogolemurins. In particular, although the smallest estimated body mass is $58 \mathrm{~g}$ for Tr. myodes using the equation by Conroy (1987), if an $M_{1}$ was known for $W$. shifrae comb. nov., its estimated body mass would certainly be lower. This is because the estimates based on teeth known for both species using the Gingerich et al. (1982) equations are consistently much lower for $W$. shifrae comb. nov. than for Tr. myodes (e.g., estimate based on $\mathrm{M}_{2}$ is $142 \mathrm{~g}$ for $T r$. myodes compared to $109 \mathrm{~g}$ for $W$. shifrae comb. nov.). This would make $W$. shifrae comb. nov. the smallest of the trogolemurins, and smaller than all other North American omomyoids (based on com- 
TABLE 1. Estimated body masses (in $\mathrm{g}$ ) of all species of Trogolemurini.

\begin{tabular}{|c|c|c|c|c|c|c|}
\hline & \multicolumn{5}{|c|}{$\begin{array}{c}\text { Gingerich et al.'s (1982) } \\
\text { equations }\end{array}$} & \multirow{2}{*}{$\begin{array}{c}\text { Conroy's }(1987 \\
M_{1} \text { equation }\end{array}$} \\
\hline & $M_{1}$ & $\mathbf{M}_{2}$ & $M_{3}$ & $\mathbf{M}^{1}$ & $\mathbf{M}^{2}$ & \\
\hline $\begin{array}{l}\text { Walshina esmaraldensis gen. } \\
\text { sp. nov. }\end{array}$ & 154 & 197 & 254 & 117 & 230 & 72 \\
\hline Walshina mcgrewi comb. nov. & 237 & 275 & - & 245 & 315 & 115 \\
\hline Walshina shifrae comb. nov. & - & 109 & 199 & 65 & 108 & - \\
\hline Trogolemur myodes & 125 & 142 & 263 & 125 & 231 & 58 \\
\hline Trogolemur amplior & - & 290 & - & - & - & - \\
\hline Trogolemur fragilis & - & - & 227 & - & - & - \\
\hline Trogolemur leonardi & - & - & - & 278 & - & - \\
\hline Sphacorhysis burntforkensis & 166 & 270 & 268 & - & - & 78 \\
\hline
\end{tabular}

parison to body mass estimates in Jones et al., 2014).

\section{PHYLOGENETIC RELATIONSHIPS OF WALSHINA GEN. NOV.}

In order to assess the phylogenetic position of Walshina gen. nov. among Omomyoidea, we conducted a cladistic analysis based on the study by $\mathrm{Ni}$ et al. (2004), as modified by Holroyd and Strait (2008), who revised the coding for two species (Purgatorius janisae and An. savagei), and added new data for species of Loveina. We chose this particular matrix rather than more recent studies (e.g., Ni et al., 2013, 2016) because it includes a trogolemurin, Tr. myodes. Having coding from a member of this family available in the original matrix was important to ensure that we were assessing characters in the same way as the original authors. The analysis also includes representative tarsioids, anthropoids, adapoids, crown strepsirrhines, and plesiadapiforms. Scandentia was used as an outgroup to Primates. The rest of the trogolemurin primates were added to the matrix of Holroyd and Strait (2008): Tr. amplior, Tr. fragilis, $T r$. leonardi, Sphacorhysis burntforkensis, W. esmaraldensis gen. et sp. nov., W. mcgrewi comb. nov., and $W$. shifrae comb. nov. The microchoerine Melaneremia bryanti (Hooker, 2007), and the anaptomorphins An. sublettensis (Gazin, 1952, 1958), An. wortmani (Bown and Rose, 1984), and An. natronensis (Beard et al., 1992) were added as well. The coding for Tr. myodes was partially reassessed, as was the one for Nannopithex sp. (to include generic variation seen in $\mathrm{Na}$. zuccolae [Hooker, 2007]), and Scandentia was re-coded for character 13. A total of 303 characters (194 dental, 49 craniomandibular, 56 postcranial, and 4 soft tis- sue and physiological [only coded for extant taxa] characters) were scored for a total of 66 taxa (matrix available on publication from www.morphobank.org under project number P3264).

A parsimony analysis was performed using TNT v. 1.5 (Goboloff and Catalano, 2016) with all characters equally weighted and ordered, following the original analysis (Ni et al., 2004; Holroyd and Strait, 2008). Multiple character states were set to be interpreted as polymorphisms, instead of uncertainties. A traditional search was implemented with 1000 repetitions. The tree-bisection-reconnection (TBR) algorithm was used for branch swapping, with 1000 trees to save per replication.

\section{Results of the Phylogenetic Analysis}

The cladistic analysis yielded 90 equally parsimonious trees. A strict consensus tree was generated in TNT v. 1.5 from these trees (Figure 7, see also Appendix 2). In the strict consensus tree, Walshina gen. nov. is found to be monophyletic, although the relationships among species of Walshina gen. nov. remain unclear. The tribe Trogolemurini was also recovered as monophyletic.

The inclusion of the rest of trogolemurins and the four additional species of omomyoids, along with the revisions made by Holroyd and Strait (2008) and in the present paper, caused a few changes to the tree with respect to the topology found by Ni et al. (2004). The position of Purgatorius is resolved in our tree, being the sister group to the rest of Primates sensu lato. The rest of Plesiadapiformes (excluding Purgatorius) form one clade, sister group of Altanius orlovi, as in $\mathrm{Ni}$ et al. (2004). However, phylogenetic analyses of plesiadapiforms with greater taxon sampling for that group support the interpretation that this group of primates is paraphyletic and excludes An. orlovi, 


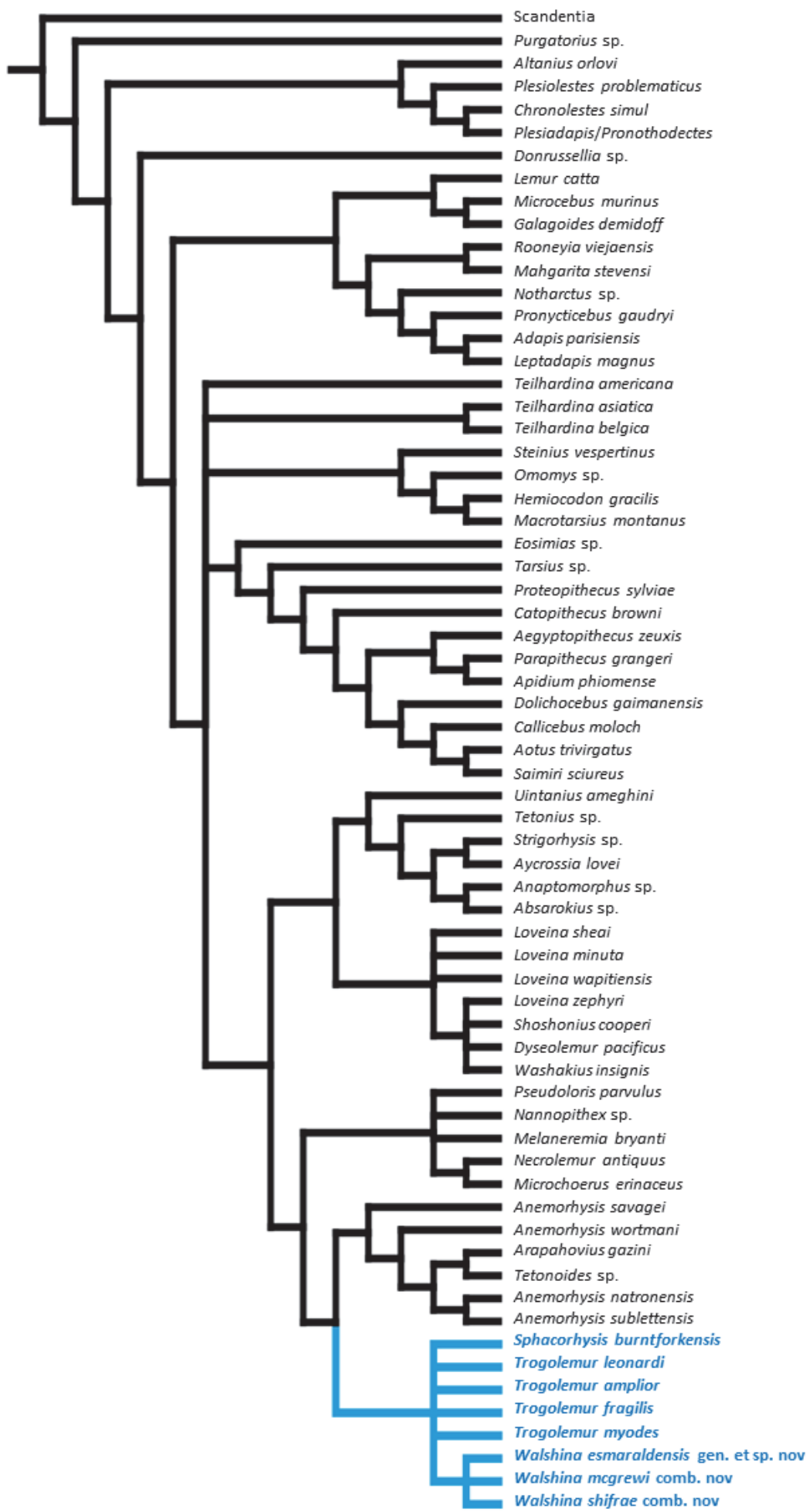

FIGURE 7. Hypothesis of relationships of Walshina gen. nov. in the context of the Order Primates. Strict consensus cladogram based on data modified from Holroyd and Strait (2008), including the addition of seven newly-coded trogolemurins (Trogolemur amplior, Tr. fragilis, Tr. leonardi, Sphacorhysis burntforkensis, Walshina esmaraldensis gen. et sp. nov., W. mcgrewi comb. nov., and W. shifrae comb. nov.), a microchoerine (Melaneremia bryanti), and three anaptomorphins (Anemorhysis sublettensis, An. wortmani, and An. natronensis). Trogolemurins are marked in blue. 
which is interpreted as a euprimate (Silcox, 2001; Bloch and Boyer, 2002; Bloch et al., 2007, Silcox et al., 2010; Chester and Bloch, 2013; Chester et al., 2015; Ni et al. 2016). The tree differs from the results obtained by $\mathrm{Ni}$ et al. (2004) in resolving the position of Donrussellia as the sister taxon to the rest of Euprimates (except for Altanius). Our tree also resolves Mahgarita and Rooneyia as sister taxa. Although Rooneyia has been considered an omomyoid, it appears as being part of the strepsirrhine radiation, as it did in $\mathrm{Ni}$ et al. (2004). All species of Teilhardina appear as basal haplorrhines, with unclear relationships among them. Eosimias appears in our tree as the sister taxon of crown haplorrhines (=Anthropoidea + Tarsius). Washakiins are monophyletic, although Loveina was found to be paraphyletic (consistent with the results of Holroyd and Strait, 2008). Our tree also resolves a clade that includes omomyins and macrotarsiins, in which omomyins are paraphyletic. Washakiins are resolved as the sister group to a subgroup of anaptomorphins, which include Uintanius, Tetonius, Strigorhysis, Aycrossia, Anaptomorphus, and Absarokius. The rest of anaptomorphins (Anemorhysis, Tetonoides, and Arapahovius) form another clade that is the sister group of trogolemurins. However, Anemorhysis does not appear to be monophyletic. The sister group to the clade (Trogolemurini + Anemorhysis + Tetonoides + Arapahovius) is the Microchoerinae from Europe. The position of trogolemurins is, therefore, in contrast with their position in the tree found by $\mathrm{Ni}$ et al. (2004), in which Trogolemur clustered together with the European microchoerines. Finding trogolemurins to be more closely related to North American anaptomorphins, rather than to European microchoerids is more biogeographically parsimonious, reducing the number of implied dispersal events between North America and Europe.

\section{DISCUSSION}

Trogolemurins have many dental features that converge on those of paromomyids, resulting in taxonomic confusion in the related literature: large hypoconulid lobes on $\mathrm{M}_{3}$, procumbent lower incisors, upper molars with a well-developed postprotocingulum and a fairly expanded distolingual basin. The most diagnostic tooth for paromomyids is the $\mathrm{P}_{4}$, which is enlarged with a tall, pointed, upright protoconid, and is very different from a trogolemurin $\mathrm{P}_{4}$, which is proportionally smaller with a mesially inclined trigonid. However, trogolemurin material has classically been scarce and incom- plete, often missing the diagnostic $\mathrm{P}_{4}$ (Robinson, 1968; Krishtalka, 1978; Mason, 1990; Storer, 1990; Walsh, 1991a; Beard et al., 1992) or the upper dentition (Matthew, 1909; Beard et al., 1992), and in many cases taxa are known only from unassociated isolated teeth (Robinson, 1968; Krishtalka, 1978; Mason, 1990; Storer, 1990; Walsh, 1991a). Trogolemurin $\mathrm{P}_{4} \mathrm{~s}$ are only known for Trogolemur and Sphacorhysis (Matthew, 1909; Emry, 1990; Gunnell, 1995), but not for Walshina gen. nov. It was not until work by Emry (1990) that the first upper molars ascribed to a trogolemurin were described, and not until work by Gunnell (1995) that the first upper dentition of Trogolemur in a tooth row (including the first $\mathrm{P}^{4}$ known for a trogolemurin) was described. This lack of knowledge about the form of the upper molars in trogolemurins led Storer (1990) to describe two complete and other fragmentary isolated upper molars as a new species of paromomyid, $\mathrm{Ph}$. leonardi, from the late middle Eocene (Duchesnean) of Saskatchewan. Beard et al. (1992) transferred Ph. leonardi to the euprimate genus Trogolemur and were the first authors to recognize the similarities between these two groups.

It is now clear that in addition to the differences in the morphology of the $\mathrm{P}_{4}$, there are important differences in upper and lower molar morphology. Paromomyids have a more quadrangular outline of the upper molars. Although both paromomyids and trogolemurins have expanded distolingual basins, the degree of expansion in trogolemurins is most comparable to the oldest paromomyids with plesiomorphic morphologies (i.e., Paromomys), which are millions of years older than the oldest trogolemurins: the oldest paromomyids are from the earliest Torrejonian, approximately 63 Ma (Clemens and Wilson, 2009) whereas the oldest trogolemurins are from the latest Wasatchian, approximately $51 \mathrm{Ma}$ (Williams and Covert, 1994). Trogolemurins are further characterized by having a large lingual expansion of the protocone lobe on the upper molars, which is not seen in any paromomyids.

The $M_{1}$ of trogolemurins differs from that tooth in paromomyids in having a very oblique, stepped postvallid, produced by a metaconid that is located well distal to the protoconid. The $M_{1}$ also has a very tall, strong paracristid, which is never so expanded in paromomyids. The hypoconulid on the $M_{1}$ and $M_{2}$ of trogolemurins is also better developed and more distinct, whereas paromomyids show weak to absent hypoconulids on these teeth. 
The talonid of the $M_{2}$ is shorter in trogolemurins relative to the length of the trigonid, making the trigonid and talonid closer in length in trogolemurins.

In sum, it is clear that in spite of the similarities between trogolemurins and paromomyids, there are numerous characters that distinguish them from one another. An additional element to the argument that the material previously ascribed to $I$. mcgrewi and Ph. shifrae does not belong in Paromomyidae is that it demonstrates morphology that would not be expected in paromomyids from so late in the family's evolutionary history. In particular, paromomyids generally exhibit increases in the degree of expansion of the upper molar distolingual basin through time, and yet the upper molars known for the Uintan and Duchesnean purported paromomyids are most comparable to those of the earliest paromomyids.

Re-classifying I. mcgrewi and Ph. shifrae as members of the new trogolemurin genus Walshina gen. nov. reframes our understanding of the timing of the demise of paromomyid diversity. Ignacius mcgrewi and $P h$. shifrae were the only members of the family identified from the Uintan and the Duchesnean, so transferring them to Omomyoidea eliminates the entire Uintan and Duchesnean record of Paromomyidae. It is worth noting, however, that even when they were considered paromomyids, there was a marked discontinuity in the record of the family between the supposed Uintan forms and the next oldest material. The first record of a paromomyid comes from the Torrejonian of Montana, specifically the Torrejonian 1 biozone (Clemens and Wilson, 2009), and from that point there is a continuous presence of this family until the latest Wasatchian (Silcox et al., 2008). Then, the next occurrence of a paromomyid is in the middle Bridgerian (Br2; Gunnell et al., 2009). The absence of paromomyids from the very large samples of mammal specimens from later in the Bridgerian (Matthew, 1909; West, 1976; Emry, 1990; Gunnell and Bartels, 1999; Gunnell et al., 2009) made the apparent reappearance of the group in the late Uintan somewhat surprising. Re-classifying the Uintan and Duchesnean material as Trogolemurini makes it clear that paromomyids were much reduced in richness after the early Bridgerian in North America. The only remaining post-Bridgerian record of a paromomyid is an isolated $\mathrm{P}^{4}$ from the Chadronian of North Dakota, tentatively ascribed by Kinm and Tornow (2014) to the genus Ignacius, which is separated from the next youngest specimen by some of the Bridgerian, and the entire Uintan and Duchesnean, indicating a very long ghost lineage that extends over a period of approximately 12 million years (middle Eocene boundary at $49 \mathrm{Ma}$, Clyde et al., 2001; Duchesnean-Chadronian boundary at 37 Ma, Prothero and Emry, 2004). The North Dakotan specimen shows clear features that ties it to paromomyids, and in particular to the genus Ignacius. The outline of the tooth is squared, instead of rectangular (as seen in Trogolemur, Gunnell, 1995), the cusps and styles are blunter, the parastylar lobe is very broad, and the postparacone and premetacone cristae meet obliquely, making a $\mathrm{V}$ shape in occlusal view, a trait observed in Ignacius.

Regardless of the apparent existence of this one surviving lineage of geographically isolated paromomyids, this family of plesiadapiforms follows a clear trend of declining biodiversity after the end of the early Eocene in North America (late Wasatchian-early Bridgerian), which is clarified by the re-classification of the Uintan and Duchesnean material. Paromomyids reached their highest peak of biodiversity during the Wasatchian 4 (Wa4) biozone, whereas only one species is found in the middle Bridgerian, Elwynella oreas (Rose and Bown, 1982; Gunnell et al., 2009). The drop in biodiversity of paromomyids could therefore be correlated with the Early Eocene Climatic Optimum (EECO), the warmest sustained period of the entire Cenozoic (Clyde et al., 2001; Zachos et al., 2008; Hyland and Sheldon, 2013; Chew, 2015). Paromomyids are also extremely rare during the Paleocene-Eocene Thermal Maximum, only known from a lower molar of $I$. graybullianus and an upper molar and an edentulous jaw of $P h$. praecox (Gingerich, 1989; Rose et al., 2012). The drop in paromomyid biodiversity during the Wasatchian 5 biozone also coincides with the warming period that precedes the EECO (including at least one hyperthermal; Chew and Oheim, 2013). In contrast, the highest peak of paromomyid biodiversity (Wa4) occurs during a cooling period between Biohorizon A and Biohorizon B (Chew and Oheim, 2013). And although the material has yet to be described in detail, paromomyids are also the only primates known from the early-middle Eocene of Ellesmere Island in the Canadian High Arctic (West and Dawson, 1977; McKenna, 1980). That part of the world is interpreted to have been much milder in the Eocene than today, but winter temperatures are still inferred to have been near freezing (Eberle and Greenwood, 2012), making this a chilly environment for primates. These various lines of evidence suggest that, as a family, paromomyids preferred cooler temperatures, and that the near 
extinction of the family in North America after the Wasatchian-Bridgerian boundary could potentially be ascribed to increasing global temperatures.

\section{Late Paromomyids from Europe}

Although the reinterpretation of most of the latest occurring purported paromomyid material from North America makes it clear that the family was largely extinct on that continent after the early Bridgerian, there are some later occurring specimens from Europe that have been attributed to the family, which could signal a longer persistence on that continent. The only known genus of paromomyid from Europe is Arcius (Russell et al., 1967; Godinot, 1984; Estravís, 2000; Marigó et al., 2012). Interestingly, the occurrence of paromomyid species in Europe through time shows some similarities to what has been observed in North America. Arcius first appears in Europe during the earliest Eocene (Mammal Paleogene zone 7 [MP7], Neustrian: Estravís, 2000), followed by a continuous presence of this family until the Grauvian (MP10; early-middle Eocene; Godinot, 2015). After that, no paromomyids are found during MP11 or MP12. It is not until MP13 (Geiseltalian) that a few teeth are reported to belong to Paromomyidae (Sudre, 1978; Rémy et al., 1997). A second lower molar of Arcius sp. from Saint-Maximin (France) is illustrated and reported in a faunal list by Rémy et al. (1997), and two third lower molars (one of them illustrated in Aumont, 2003) from Bouxwiller (France) appear in a faunal list in Sudre (1978). However, this scarce material, comprised of three isolated molars from the middle Eocene of Europe, might not be paromomyids.

The tooth from Saint-Maximin, identified here as an $\mathrm{M}_{2}$ (and as either an $\mathrm{M}_{1}$ or an $\mathrm{M}_{2}$ by Rémy et al., 1997), is strikingly different from that tooth in any Arcius species. It has a prominent paraconid, which is not consistent with what it is observed in a typical Arcius $\mathrm{M}_{2}$. Also, the trigonid area is significantly larger in relation to the talonid than in any species of Arcius. We suggest that it could be a diminutive adapoid, and tentatively ascribe it to cf. Anchomomys sp., based on the presence of this genus at that site. The $\mathrm{M}_{3}$ s from Bouxwiller were identified as Arcius lapparenti by Aumont (2003). However, they are very flat and significantly shorter mesiodistally than those of Ar. lapparenti. The trigonid is shorter mesiodistally in relation to its width than in Ar. lapparenti, and the buccolingual dimension from the hypoconid to the entoconid is significantly greater than in any species of Arcius. Also, the hypoconulid lobe, although expanded, is signifi- cantly smaller than the ones seen in any Eocene paromomyids. Therefore, we suggest that it could potentially be a microchoerid omomyoid, and tentatively ascribe these teeth to cf. Nannopithex sp., based on the presence of this genus at that site. The fact that the Geiseltalian material likely belongs to diminutive euprimates rather than to the Paromomyidae is consistent with the near extinction of paromomyids after the early middle Eocene observed in North America.

\section{CONCLUSIONS}

The material from southern California previously ascribed to Phenacolemur by Mason (1990) and Walsh (1991a) are not paromomyids. They represent a new species of trogolemurin omomyoid, $W$. esmaraldensis gen. et sp. nov. The Californian sample of Walshina gen. nov. adds to our knowledge of the variability and diversity of omomyoids, particularly trogolemurins, and significantly changes our understanding of the temporal distribution of the plesidapiform family Paromomyidae. The former paromomyids I. mcgrewi and Ph. shifrae from the Uintan and Duchesnean of Wyoming are transferred to the genus Walshina gen. nov., eliminating any record of paromomyids from the Uintan and the Duchesnean. The nearly complete lack of paromomyids after the onset of the Bridgerian could be correlated with the warmest sustained period of the Cenozoic, the EECO. This pattern is consistent with the disappearance of paromomyids after the Grauvian in Europe, making this a generalized trend of extinction or near extinction of this group worldwide in the middle Eocene.

Trogolemurin omomyoids and paromomyid plesiadapiforms converge in general dental morphology, suggesting that they might have been eating similar foods. It is notable that omomyoids with this morphology appear only after the near extinction of paromomyids in North America, suggesting that perhaps the marked decline in paromomyids left niche space available for omomyoids. The sole remaining late occurrence of a paromomyid, from the Chadronian of North Dakota, has been interpreted as being part of a relictual fauna surviving in the Great Plains, distinct from the Rocky Mountain province (Kinm and Tornow, 2014). Perhaps survival of a paromomyid in that context was made possible by its isolation from ecologically similar trogolemurin omomyoids.

Finally, our phylogenetic analysis shows that Walshina gen. nov. is monophyletic, nested inside Trogolemurini. The most closely related group to trogolemurins is a clade of anaptomorphins com- 
posed by Anemorhysis, Tetonoides, and Arapahovius. Therefore, our phylogenetic analysis is consistent with the previously inferred close relationship of trogolemurins to Anemorhysis (Williams, 1994; Williams and Covert, 1994; Tornow, 2008) and to Tetonoides and Arapahovius (Gunnell, 1995). Although the most recent definition of Trogolemurini by Gunnell and Rose (2002) is fairly constricted in number of genera, our phylogenetic results are consistent with a broader definition of Trogolemurini suggested by Beard et al. (1992), in which Anemorhysis, Tetonoides, and Arapahovius might also be included.

\section{ACKNOWLEDGMENTS}

We would like to thank W.A. Clemens (UCMP), T.A. Deméré, and K.A. Randall (SDSNH), T. Tokaryk, R.C. McKellar, and H. Bryant (RSM), A.R. Tabrum (CMNH), J.J. Eberle, T. Culver, and T. Karim (UCM) for access to specimens and/or casts. We thank T.M. Bown, M.A. Tornow, and T.B. Viola for relevant discussions. Thanks to D.R.
Begun, W.A. Clemens, G.F. Gunnell, and M.A. Schillaci for comments on a previous version of this manuscript. We are thankful to the Editorial Crew of Palaeontologia Electronica and three anonymous reviewers for comments that substantially improved this paper. Thanks to R. Bhagat for the making of relevant casts. We are very grateful to J.T. Gladman for his assistance in CT-scanning the specimens of Walshina gen. nov. Thanks to K.R. Selig for further assistance during scanning. Photographs were taken and edited by G. San Martin Flores, D. Lin, PAH, MTS, and SLT. We are grateful to D.M. Boyer, G. Dewar, and J.A. Teichroeb for access to resources. Thanks to R. Blakey (Colorado Plateau Geosystems, Inc., USA) for the permission to use paleogeographical maps. This research was supported by the Doris $\mathrm{O}$. and Samuel P. Welles Research Fund and a University of Toronto Department of Anthropology Research Travelling Grant to SLT, and an NSERC Discovery Grant to MTS.

\section{REFERENCES}

Abbott, P.L. 1999. Rise and fall of San Diego: 150 million years of history recorded in sedimentary rocks. 1st Edition. Sunbelt Publications, San Diego, California.

Aumont, A. 2003. Systématique et phylogénie des Paromomyidés européens. Unpublished Ph.D. thesis, Muséum National d'Histoire Naturelle, Paris, France.

Beard, K.C. 1989. Postcranial anatomy, locomotor adaptations, and paleoecology of early Cenozoic Plesiadapidae, Paromomyidae, and Micromomyidae (Eutheria, Dermoptera). Unpublished Ph.D. thesis, Johns Hopkins University, Baltimore, Maryland, USA.

Beard, K.C. 1990. Gliding behaviour and palaeoecology of the alleged primate family Paromomyidae (Mammalia, Dermoptera). Nature, 345:340-341. https://doi.org/10.1038/ $345340 \mathrm{a} 0$

Beard, K.C. 1993a. Phylogenetic systematics of the Primatomorpha, with special reference to Dermoptera, p. 129-150. In Szalay, F.S., Novacek, M.J., and McKenna, M.C. (eds.), Mammal Phylogeny: Placentals. Springer-Verlag, New York.

Beard, K.C. 1993b. Origin and evolution of gliding in early Cenozoic Dermoptera (Mammalia, Primatomorpha), p. 63-90. In MacPhee, R.D.E. (ed.), Primates and Their Relatives in Phylogenetic Perspective. Plenum Press, New York.

Beard, K.C., Krishtalka, L., and Stucky, R.K. 1992. Revision of the Wind River faunas, early Eocene of central Wyoming. Part 12. New species of omomyid primates (Mammalia: Primates: Omomyidae) and omomyid taxonomic composition across the early-middle Eocene boundary. Annals of the Carnegie Museum, 61:39-62.

Berry, R.W. 1999. Eocene and Oligocene Otay-type waxy bentonites of San Diego County and Baja California; chemistry, mineralogy, petrology and plate tectonic implications. Clays and Clay Minerals, 47:70-83.

Bloch, J.I. and Boyer, D.M. 2002. Grasping primate origins. Science, 298:1606-1610. https:// doi.org/10.1126/science.1078249

Bloch, J.I. and Boyer, D.M. 2007. New skeletons of Paleocene-Eocene Plesiadapiformes: a diversity of arboreal positional behaviors in early primates, p. 535-581. In Ravosa, M.J. and Dagosto, M. (eds.), Primate Origins: Adaptations and Evolution. Plenum Press, Springer, New York. https://doi.org/10.1007/978-0-387-33507-0 
Bloch, J.I., Silcox, M.T., Boyer, D.M., and Sargis, E.J. 2007. New Paleocene skeletons and the relationship of plesiadapiforms to crown-clade primates. Proceedings of the National Academy Sciences of the United States of America, 104:1159-1164. https://doi.org/10.1073/ pnas.0610579104

Bottjer, D.J., Lund, S.P., Powers, J.E., Steele, M.C., and Squires, R.L. 1991. Magnetostratigraphy of Paleogene strata in San Diego and the Simi Valley, southern California, p. 115-124. In Abbott, P.L. and May, J.A. (eds.), Eocene Geologic History, San Diego Region. Pacific Section, Society of Economic Paleontologists and Mineralogists.

Bown, T.M and Rose, K.D. 1976. New early Tertiary Primates and a reappraisal of some Plesiadapiformes. Folia Primatologica, 26:109-138. https://doi.org/10.1159/000155734

Bown, T.M. and Rose, K.D. 1984. Reassessment of some early Eocene Omomyidae, with description of a new genus and three new species. Folia Primatologica, 43:97-112. https:// doi.org/10.1159/000156175

Boyer, D.M. and Bloch, J.I. 2008. Evaluating the Mitten-Gliding Hypothesis for Paromomyidae and Micromomyidae (Mammalia, "Plesiadapiformes") using comparative functional morphology of new Paleogene skeletons, p. 233-284. In Sargis, E.J. and Dagosto, M. (eds.), Mammalian Evolutionary Morphology: A Tribute to Frederick S. Szalay. Springer-Verlag, New York. https://doi.org/10.1007/978-1-4020-6997-0_11

Chester, S.G.B. and Bloch, J.I. 2013. Systematics of Paleogene Micromomyidae (Euarchonta, Primates) from North America. Journal of Human Evolution, 65:109-142. https://doi.org/ 10.1016/j.jhevol.2013.04.006

Chester, S.G.B., Bloch, J.I., Boyer, D.M., and Clemens, W.A. 2015. Oldest known euarchontan tarsals and affinities of Paleocene Purgatorius to Primates. Proceedings of the National Academy Sciences of the United States of America, 112:1487-1492. https://doi.org/10.1073/ pnas.1421707112

Chew, A.E. 2015. Mammal faunal change in the zone of the Paleogene hyperthermals ETM2 and H2. Climate of the Past, 11:1223-1237. https://doi.org/10.5194/cp-11-1223-2015

Chew, A.E. and Oheim, K.B. 2013. Diversity and climate change in the middle-late Wasatchian (early Eocene) Willwood Formation, central Bighorn Basin, Wyoming. Palaeogeography, Palaeoclimatology, Palaeoecology, 369:67-78. https://doi.org/10.1016/j.palaeo.2012.10.004

Clemens, W.A. and Wilson, G.P. 2009. Early Torrejonian mammalian local fauna from northeastern Montana, U.S.A. In Albright, L.B., III (ed.), Papers on Geology, Vertebrate Paleontology, and Biostratigraphy in Honor of Michael O. Woodburne. Museum of Northern Arizona Bulletin, 65: 111-158.

Clyde, W.C., Sheldon, N.D., Koch, P.L., Gunnell, G.F., and Bartels, W.S. 2001. Linking the Wasatchian/Bridgerian boundary to the Cenozoic Global Climate Optimum: New magnetostratigraphic and isotopic results from South Pass, Wyoming. Palaeogeography, Palaeoclimatology, Palaeoecology, 167:175-199. https://doi.org/10.1016/S00310182(00)00238-8

Colbert, M.W. 2006. Hesperaletes (Mammalia: Perissodactyla), a new tapiroid from the middle Eocene of southern California. Journal of Vertebrate Paleontology, 26:697-711. https:// doi.org/10.1671/0272-4634(2006)26[697:HMPANT]2.0.CO;2

Conroy, G.C. 1987. Problems of body-weight estimation in fossil primates. International Journal of Primatology, 8:115-137. https://doi.org/10.1007/BF02735160

Cope, E.D. 1883. On the mutual relations of the bunotherian Mammalia. Proceedings of the Academy of Natural Sciences of Philadelphia, 35:77-83.

Eaton, J.G. 1982. Paleontology and correlation of Eocene volcanic rocks in the Carter Mountain area, Park County, southeastern Absarokia Range, Wyoming. Contributions to Geology, University of Wyoming, 21:153-194.

Eberle, J.J. and Greenwood, D.R. 2012. Life at the top of the greenhouse Eocene world - A review of the Eocene flora and vertebrate fauna from Canada's High Arctic. Geological Society of America Bulletin, 124:3-23. https://doi.org/10.1130/B30571.1

Emry, R.J. 1990. Mammals of the Bridgerian (middle Eocene) Elderberry Canyon local fauna of eastern Nevada, p. 187-210. In Bown, T.M. and Rose, K.D. (eds.), Dawn of the Age of Mammals in the Northern Part of the Rocky Mountain Interior, North America. Geological Society of America, Special Paper 243, Boulder.

Estravís, C. 2000. Nuevos mamíferos del Eoceno Inferior de Silveirinha (Baixo Mondego, Portugal). Coloquios de Paleontología, 51:281-311. 
Frederiksen, N.O. 1991. Pulses of middle Eocene to earliest Oligocene climatic deterioration in southern California and the Gulf Coast. Palaios, 6:564-571. https://doi.org/10.2307/3514919

Gazin, C.L. 1952. The lower Eocene Knight Formation of western Wyoming and its mammalian faunas. Smithsonian Miscellaneous Collections, 117:1-82.

Gazin, C.L. 1958. A review of the middle and upper Eocene primates of North America. Smithsonian Miscellaneous Collections, 136:1-112.

Gingerich, P.D. 1989. New earliest Wasatchian mammalian fauna from the Eocene of northwestern Wyoming: composition and diversity in a rarely sampled high-floodplain assemblage. University of Michigan Papers on Paleontology, 28:1-97.

Gingerich, P.D., Smith, B.H., and Rosenberg, K. 1982. Allometric scaling in the dentition of primates and prediction of body weight from tooth size in fossils. American Journal of Physical Anthropology, 58:81-100. https://doi.org/10.1002/ajpa.1330580110

Goboloff P.A. and Catalano S.A. 2016. TNT version 1.5, including a full implementation of phylogenetic morphometrics. Cladistics, 32:221-238. https://doi.org/10.1111/cla.12160

Godinot, M. 1984. Un nouveau genre de Paromomyidae (Primates) de l'Eocène Inférieur d'Europe. Folia Primatologica, 43:84-96. https://doi.org/10.1159/000156174

Godinot, M. 2015. Fossil record of the Primates from the Paleocene to the Oligocene, p. 1-102. In Henke, W. and Tattersall, I. (eds.), Handbook of Paleoanthropology. Springer Berlin Heidelberg, Berlin. https://doi.org/10.1007/978-3-642-39979-4_68

Golz, D.J. 1976. Eocene Artiodactyla of southern California. Los Angeles County Natural History Museum Bulletin, 26:1-85.

Golz, D.J. and Lillegraven, J.A. 1977. Summary of known occurrences of terrestrial vertebrates from Eocene strata of southern California. Contributions to Geology, University of Michigan, 15:43-64.

Gunnell, G.F. 1995. Omomyid primates (Tarsiiformes) from the Bridger Formation, middle Eocene, southern Green River Basin, Wyoming. Journal of Human Evolution, 28:147-187. https://doi.org/10.1006/jhev.1995.1012

Gunnell, G.F. and Bartels, W.S. 1999. Middle Eocene vertebrates from the Uinta Basin, Utah, and their relationship with faunas from the southern Green River Basin, Wyoming. In Gillette, D.D. (ed.), Vertebrate Paleontology of Utah. Utah Geological Survey Miscellaneous Publication, 99:429-442.

Gunnell, G.F., Murphey, P.C., Stucky, R.K., Townsend, K.E.B., Robinson, P., Zonneveld, J.-P., and Bartels, W.S. 2009. Biostratigraphy and biochronology of the latest Wasatchian, Bridgerian, and Uintan of North American Land Mammal "Ages". In Albright, L.B., III (ed.), Papers on Geology, Vertebrate Paleontology, and Biostratigraphy in Honor of Michael O. Woodburne. Museum of Northern Arizona Bulletin, 65:279-330.

Gunnell, G.F. and Rose, K.D. 2002. Tarsiiformes: Evolutionary history and adaptation, p. 91-109. In Hartwig, W.C. (ed.), The Primate Fossil Record. Cambridge University Press, Cambridge.

Hamrick, M.W., Rosenman, B.A., and Brush, J.A. 1999. Phalangeal morphology of the Paromomyidae (?Primates, Plesiadapiformes): the evidence for gliding behavior reconsidered. American Journal of Physical Anthropology, 109:397-413. https://doi.org/ 10.1002/(SICl)1096-8644(199907)109:3<397::AID-AJPA8>3.0.CO;2-9

Holroyd, P.A. and Strait, S.G. 2008. New data on Loveina (Primates: Omomyidae) from the early Eocene Wasatch Formation and implications for washakiin relationships, p. 243-257. In Fleagle, J.G. and Gilbert, C.C. (eds.), Elwyn Simons: A Search for Origins. Springer Science+Business Media, New York. https://doi.org/10.1007/978-0-387-73896-3

Hooker, J.J. 2007. A new microchoerine omomyid (Primates, Mammalia) from the English early Eocene and it palaeobiogeographical implications. Palaeontology, 50:739-756. https:// doi.org/10.1111/j.1475-4983.2007.00655.x

Hooker, J.J. 2010. The mammal fauna of the early Eocene Blackheath Formation of Abbey Wood, London. Monograph of the Palaeontological Society, 165:1-162.

Howard, J.L. and Lowry, W.D. 1995. Medial Cenozoic paleogeography of the Los Angeles area, south-western California, and adjacent parts of the United States, p. 22-41. In Fritsche, A.E. (ed.), Cenozoic paleogeography of the western United States-II. Pacific Section, Society of Economic Paleontologists and Mineralogists.

Hyland, E.G. and Sheldon, N.D. 2013. Coupled $\mathrm{CO}_{2}$-climate response during the Early Eocene Climate Optimum. Palaeogeography, Palaeoclimatology, Palaeoecology, 369:125-135. https://doi.org/10.1016/j.palaeo.2012.10.011 
Jones, K.E., Rose, K.D., and Perry, J.M.G. 2014. Body size and premolar evolution in the earlymiddle Eocene Euprimates of Wyoming. American Journal of Physical Anthropology, 153:1528. https://doi.org/10.1002/ajpa.22387

Kay, R.F., Thewissen, J.G.M., and Yoder, A.D. 1992. Cranial anatomy of Ignacius graybullianus and the affinities of Plesiadapiformes. American Journal of Physical Anthropology, 89:477498. https://doi.org/10.1002/ajpa.1330890409

Kay, R.F., Thorington, R.W., Jr., and Houde, P. 1990. Eocene plesiadapiform shows affinities with flying lemurs not primates. Nature, 345:342-344. https://doi.org/10.1038/345342a0

Kelly, T.S. 1990. Biostratigraphy of Uintan and Duchesnean land mammal assemblages from the middle member of the Sespe Formation, Simi Valley, California. Contributions in Science, Natural History Museum of Los Angeles County, 419:1-22.

Kelly, T.S., Lander, E.B., Whistler, D.P., Roeder, M.A., and Reynolds, R.E. 1991. Preliminary report on a paleontologic investigation of the lower and middle members, Sespe Formation, Simi Valley Landfill, Ventura County, California. PaleoBios, 13:1-13.

Kelly, T.S., Murphey, P.C., and Walsh, S.L. 2012. New records of small mammals from the middle Eocene Duchesne River Formation, Utah, and their implications for the Uintan-Duchesnean North American Land Mammal Age transition. Paludicola, 8:208-251.

Kinm, A.J. and Tornow, M.A. 2014. First occurrence of plesiadapiform primates from the Chadronian (latest Eocene). Paludicola, 9:176-182.

Krause, D.W. 1991. Were paromomyids gliders? Maybe, maybe not. Journal of Human Evolution, 21:177-188. https://doi.org/10.1016/0047-2484(91)90060-9

Krishtalka, L. 1978. Paleontology and geology of the Badwater Creek Area, central Wyoming. Part 15. Review of the late Eocene primates from Wyoming and Utah, and the Plesitarsiiformes. Annals of the Carnegie Museum, 47:335-360.

Lillegraven, J.A. 1979. A biogeographical problem involving comparisons of later Eocene terrestrial vertebrate faunas of Western North America, p. 333-347. In Gray, J. and Boucot, A.J. (eds.), Historical Biogeography, Plate Tectonics, and the Changing Environment. Oregon State University Press, Corvallis.

Lillegraven, J.A. 1980. Primates from later Eocene rocks of southern California. Journal of Mammalogy, 61:181-204. https://doi.org/10.2307/1380040

Lindsay, E.H. 1968. Rodents from the Hartman Ranch local fauna, California. PaleoBios, 6:1-20.

Link, M.H., Peterson, G.L., and Abbott, P.L. 1979. Eocene depositional systems, San Diego, California, p. 1-17. In Abbott, P.L. (ed.), Eocene Depositional Systems, San Diego. Pacific Section, Society of Economic Paleontologists and Mineralogists.

Linnaeus, C. 1758. Systema naturae per regna tria naturae, secundum classes, ordines, genera, species, cum characteribus, differentiis, synonymis, locis. Laurentii Salvii, Stockholm.

Ludtke, J.A. and Prothero, D.R. 2004. Taxonomic revision of the middle Eocene (UintanDuchesnean) protoceratid Leptoreodon (Mammalia: Artiodactyla). New Mexico Museum of Natural History and Science Bulletin, 26:101-110.

Marigó, J., Minwer-Barakat, R., Moyà-Solà, S., and López-Torres, S. 2012. First record of Plesiadapiformes (Primates, Mammalia) from Spain. Journal of Human Evolution, 62:429433. https://doi.org/10.1016/j.jhevol.2012.01.002

Marigó, J., Susanna, I., Minwer-Barakat, R., Madurell-Malapeira, J., Moyà-Solà, S., CasanovasVilar, I., Robles, J.M., and Alba, D.M. 2014. The primate fossil record of the Iberian Peninsula. Journal of Iberian Geology, 40:179-211. https://doi.org/10.5209/ rev_JIGE.2014.v40.n1.44094

Mason, M.A. 1988. Mammalian paleontology and stratigraphy of the early to middle Tertiary Sespe and Titus Canyon Formations, southern California. Unpublished Ph.D. thesis, University of California, Berkeley, California, USA.

Mason, M.A. 1990. New fossil primates from the Uintan (Eocene) of southern California. PaleoBios, 13:1-7.

Matthew, W.D. 1909. The Carnivora and Insectivora of the Bridger Basin, middle Eocene. Memoirs of the American Museum of Natural History, 9:289-576.

Matthew, W.D. 1915. A revision of the lower Eocene Wasatch and Wind River faunas. Part IV Entelonychia, Primates, Insectivora (Part). Bulletin of the American Museum of Natural History, 37:831-839.

Matthew, W.D. and Granger, W. 1921. New genera of Paleocene mammals. American Museum Novitates, 13:1-7. 
McKenna, M.C. 1980. Eocene paleolatitude, climate, and mammals of Ellesmere Island. Palaeogeography, Palaeoclimatology, Palaeoecology, 30:349-362. https://doi.org/10.1016/ 0031-0182(80)90065-6

McQuarrie, N. and Wernicke, B.P. 2005. An animated tectonic reconstruction of southwestern North America since 36 Ma. Geosphere, 1:147-172. https://doi.org/10.1130/GES00016.1

Ni, X., Gebo, D.L., Dagosto, M., Meng, J., Tafforeau, P., Flynn, J.J., and Beard, K.C. 2013. The oldest known primate skeleton and early haplorhine evolution. Nature, 498:60-64. https:// doi.org/10.1038/nature12200

$\mathrm{Ni}, \mathrm{X}$., Li, Q., Li, L., and Beard, K.C. 2016. Oligocene primates from China reveal divergence between African and Asian primate evolution. Science, 352:673-677. https://doi.org/10.1126/ science.aaf2107

Ni, X., Wang, Y., Hu, Y., and Li, C. 2004. A euprimate skull from the early Eocene of China. Nature, 427:65-68. https://doi.org/10.1038/nature02126

Novacek, M.J. and Lillegraven, J.A. 1979. Terrestrial vertebrates from the later Eocene of San Diego County, California: a conspectus, p. 69-80. In Abbott, P.L. (ed.), Eocene Depositional Systems, San Diego. Pacific Section, Society of Economic Paleontologists and Mineralogists.

Ogg, J.G. 2012. Geomagnetic Polarity Time Scale, p. 85-113. In Gradstein, F.M., Ogg, J.G., Schmitz, M.D., and Ogg, G.M. (eds.), The Geologic Time Scale. Elsevier, Boston. https:// doi.org/10.1016/C2011-1-08249-8

Penkrot, T.A. and Zack, S.P. 2016. Tarsals of Sespedectinae (?Lipotyphla) from the middle Eocene of southern California, and the affinities of Eocene 'erinaceomorphs'. Journal of Vertebrate Paleontology, e1212059. https://doi.org/10.1080/02724634.2016. 1212059

Peterson, G.L. and Abbott, P.L. 1979. Mid-Eocene climatic change, southwestern California and northwestern Baja California. Palaeogeography, Palaeoclimatology, Palaeoecology, 26:7387. https://doi.org/10.1016/0031-0182(79)90141-X

Pocock, R.I. 1918. On the external characters of the lemurs and of Tarsius. Proceedings of the Zoological Society of London, 88:19-53. https://doi.org/10.1111/j.1096-3642.1918.tb02076.x

Prothero, D.R. 2001a. Magnetostratigraphic tests of sequence stratigraphic correlations from the southern California Paleogene. Journal of Sedimentary Research B, 71:525-535. https:// doi.org/10.1306/051500710526

Prothero, D.R. 2001b. Magnetic stratigraphy of the middle-upper Eocene Santiago Formation, Orange and San Diego Counties, California. Guidebook, Pacific Section, Society of Economic Paleontologists and Mineralogists, 91:107-118.

Prothero, D.R. and Emry, R.J. 2004. The Chadronian, Orellan, and Whitneyan North American land mammal ages, p. 156-168. In Woodburne, M.O. (ed.), Late Cretaceous and Cenozoic Mammals of North America: Biostratigraphy and Geochronology. Columbia University Press, New York.

Prothero, D.R., Howard, J.L., and Dozier, T.H.H. 1996. Stratigraphy and paleomagnetism of the upper middle Eocene to lower Miocene (Uintan to Arikareean) Sespe Formation, Ventura County, California, p. 171-188. In Prothero, D.R. and Emry, R.J. (eds.), The Terrestrial Eocene-Oligocene Transition in North America. Cambridge University Press, New York.

Rémy, J.A., Aguilar, J.-P., Crochet, J.-Y., Duffaud, S., Escarguel, G., Godinot, M., Marandat, B., Michaux, J., Rage, J.-C., Sigé, B., Sudre, J., and Wiénin, M. 1997. Les remplissages karstiques polyphasés (Éocène, Oligocène, Pliocène) de Saint-Maximin (phosphorites du Gard) et leur apport à la connaissance des faunes européennes, notamment pour l'Éocène moyen (MP 13). 1.- Introduction, systématique (pars) et synthèse, p. 711-728. In Aguilar, J.P., Legendre, S., and Michaux, J. (eds.), Actes du Congrès BiochoM'97. Mémoires et Travaux de l'École Pratique des Hautes Études, Institut de Montpellier.

Robinson, P. 1968. The paleontology and geology of the Badwater Creek area, central Wyoming Part 4. Late Eocene primates from Badwater, Wyoming, with a discussion of material from Utah. Annals of Carnegie Museum, 39:307-326.

Robinson, P., Gunnell, G.F., Walsh, S.L., Clyde, W.C., Storer, J.E., Stucky, R.K., Froehlich, D.J., Ferrusquía-Villafranca, I., and McKenna, M.C. 2004. Wasatchian through Duchesnean biochronology, p. 106-155. In Woodburne, M.O. (ed.), Late Cretaceous and Cenozoic Mammals of North America. Columbia University Press, New York.

Rose, K.D. and Bown, T.M. 1982. New plesiadapiform primate from the Eocene of Wyoming and Montana. Journal of Vertebrate Paleontology, 2:63-69. https://doi.org/10.1080/ 02724634.1982.10011918 
Rose, K.D., Chester, S.G.B., Dunn, R.H., Boyer, D.M., and Bloch, J.I. 2011. New fossils of the oldest North American euprimate Teilhardina brandti (Omomyidae) from the PaleoceneEocene thermal maximum. American Journal of Physical Anthropology, 146:281-305. https:// doi.org/10.1002/ajpa.21579

Rose, K.D., Chew, A.E., Dunn, R.H., Kraus, M.J., Fricke, H.C., and Zack, S.P. 2012. Earliest Eocene mammalian fauna from the Paleocene-Eocene Thermal Maximum at Sand Creek Divide, southern Bighorn Basin, Wyoming. University of Michigan Papers on Paleontology, $36: 1-122$.

Ross, C., Williams, B.A., and Kay, R.F. 1998. Phylogenetic analysis of anthropoid relationships. Journal of Human Evolution, 35:221-306. https://doi.org/10.1006/jhev.1998.0254

Roth, B. 1988. Camaenid land snails (Gastropoda: Pulmonata) from the Eocene of southern California and their bearing on the history of the American Camaenidae. Transactions of the San Diego Society of Natural History, 21:203-220.

Roth, B. 1991. Tropical "physiognomy" of a land snail faunule from the Eocene of southern California. Malacologia, 33:281-288.

Runestad, J.A. and Ruff, C.B. 1995. Structural adaptations for gliding in mammals with implications for locomotor behavior in paromomyids. American Journal of Physical Anthropology, 98:101-119. https://doi.org/10.1002/ajpa.1330980202

Russell, D.E., Louis, P., and Savage, D.E. 1967. Primates of the French early Eocene. University of California Publications in Geological Sciences, 73:1-46.

Sargis, E.J. 2002. The postcranial morphology of Ptilocercus lowii (Scandentia, Tupaiidae): an analysis of Primatomorpha and volitantian characters. Journal of Mammalian Evolution, 9:137-160. https://doi.org/10.1023/A:1021387928854

Schiebout, J.A. 1974. Vertebrate paleontology and paleoecology of Paleocene Black Peaks Formation, Big Bend National Park, Texas. Texas Memorial Museum Bulletin, 24:1-88.

Silcox, M.T. 2001. A phylogenetic analysis of the Plesiadapiformes and their relationship to Euprimates and other archontans. Unpublished Ph.D. thesis, Johns Hopkins University, Baltimore, Maryland, USA.

Silcox, M.T., Bloch, J.I., Boyer, D.M., Chester, S.G.B., and López-Torres, S. 2017. TThe evolutionary radiation of plesiadapiforms. Evolutionary Anthropology, 26:74-94. https:// doi.org/10.1002/evan.21526

Silcox, M.T., Bloch, J.I., Boyer, D.M., and Houde, P. 2010. Cranial anatomy of Paleocene and Eocene Labidolemur kayi (Mammalia, Apatotheria), and the relationships of the Apatemyidae to other mammals. Zoological Journal of the Linnean Society, 160:773-825. https://doi.org/ 10.1111/j.1096-3642.2009.00614.x

Silcox, M.T. and Gunnell, G.F. 2008. Plesiadapiformes, p. 207-238. In Janis, C.M., Gunnell, G.F., and Uhen, M.D. (eds.), Evolution of Tertiary Mammals of North America. Cambridge University Press, Cambridge.

Silcox, M.T., Rose, K.D., and Bown, T.M. 2008. Early Eocene Paromomyidae (Mammalia, Primates) from the southern Bighorn Basin, Wyoming: systematics and evolution. Journal of Paleontology, 82:1074-1113. https://doi.org/10.1017/S0022336000055311

Smith, T., Rose, K.D., and Gingerich, P.D. 2006. Rapid Asia-Europe-North America geographic dispersal of earliest Eocene primate Teilhardina during the Paleocene-Eocene Thermal Maximum. Proceedings of the National Academy of Sciences of the United States of America, 103:11223-11227. https://doi.org/10.1073/pnas.0511296103

Stafford, B.J. and Thorington, R.W., Jr. 1998. Carpal development and morphology in archontan mammals. Journal of Morphology, 235:135-155. https://doi.org/10.1002/(SICI)10974687(199802)235:2<135::AID-JMOR4>3.0.CO;2-8

Stock, C. 1934a. Microsyopinae and Hyopsodontidae in the Sespe Upper Eocene, California. Proceedings of the National Academy of Sciences of the United States of America, 20:349354. https://doi.org/10.1073/pnas.20.6.349

Stock, C. 1934b. New Creodonta from the Sespe Upper Eocene, California. Proceedings of the National Academy of Sciences of the United States of America, 20:423-427. https://doi.org/ 10.1073/pnas.20.7.423

Stock, C. 1935. Insectivora from the Sespe uppermost Eocene, California. Proceedings of the National Academy of Sciences of the United States of America, 21:214-219. https://doi.org/ 10.1073/pnas.21.4.214

Stock, C. 1936. Sespe Eocene didelphids. Proceedings of the National Academy of Sciences of the United States of America, 22:122-124. https://doi.org/10.1073/pnas.22.2.122 
Stock, C. 1938. A tarsiid primate and a mixodectid from the Poway Eocene, California. Proceedings of the National Academy of Sciences of the United States of America, 24:288293. https://doi.org/10.1073/pnas.24.7.288

Stock, C. 1948. Pushing back the history of land mammals in western North America. Geological Society of America Bulletin, 59:327-332.

Storer, J.E. 1990. Primates of the Lac Pelletier lower fauna (Eocene: Duchesnean), Saskatchewan. Canadian Journal of Earth Sciences, 27:520-524. https://doi.org/10.1139/ e90-048

Sudre, J. 1978. Les artiodactyles de l'Éocène moyen et supérieur d'Europe occidentale, systématique et évolution. Mémoires et Travaux de l'Institut de Montpellier de l'École Pratique Hautes Études, 7:1-229.

Szalay, F.S. 1976. Systematics of the Omomyidae (Tarsiiformes, Primates). Taxonomy, phylogeny, and adaptations. Bulletin of the American Museum of Natural History, 156:157450.

Theodor, J.M. 1999. Protoreodon walshi, a new species of agriochoerid (Oreodonta, Artiodactyla, Mammalia) from the late Uintan of San Diego County, California. Journal of Paleontology, 73:1179-1190. https://doi.org/10.1017/S0022336000031061

Tomiya, S. 2013. New carnivoraforms (Mammalia) from the middle Eocene of California, USA and comments on the taxonomic status of "Miacis" gracilis. Palaeontologia Electronica, 16.2.14A:1-29. https://doi.org/10.26879/364

Tong, Y. and Wang, J. 1998. A preliminary report on the early Eocene mammals of the Wutu fauna, Shangdong Province, China, p. 186-193. In Beard, K.C. and Dawson, M.R. (eds.), Dawn of the Age of Mammals in Asia. Bulletin of the Carnegie Museum of Natural History, 34:186-193.

Tornow, M.A. 2008. Systematic analysis of the Eocene primate family Omomyidae using gnathic and postcranial data. Bulletin of the Peabody Museum of Natural History, 49:43-129. https:// doi.org/10.3374/0079-032X(2008)49[43:SAOTEP]2.0.CO;2

Trouessart, E.-L. 1879. Catalogue des mammifères vivants et fossiles. Insectivores. Revue et Magasin de Zoologie Pure et Appliquée, 7:219-285.

Walsh, S.L. 1987. Mammalian paleontology of the southern outcrops of the Mission Valley Formation, San Diego County, California. Unpublished undergraduate thesis, Department of Geology, San Diego State University, San Diego, California, USA.

Walsh, S.L. 1991a. Eocene mammal faunas of San Diego County, p. 161-167. In Abbot, P.L. and May, J.A. (eds.), Eocene Geologic History San Diego Region. Pacific Section, Society of Economic Paleontologists and Mineralogists.

Walsh, S.L. 1991b. Late Eocene mammals from the Sweetwater Formation, San Diego County, California, p. 149-159. In Abbot, P.L. and May, J.A. (eds.), Eocene Geologic History San Diego Region. Pacific Section, Society of Economic Paleontologists and Mineralogists.

Walsh, S.L. 1996. Middle Eocene faunas of San Diego County, California, p. 75-119. In Prothero, D.R. and Emry, R.J. (eds.), The Terrestrial Eocene-Oligocene Transition in North America. Cambridge University Press, Cambridge.

Walsh, S.L. 1997. New specimens of Metanoiamys, Pauromys, and Simimys (Rodentia: Myomorpha) from the Uintan (middle Eocene) of San Diego County, California, and comments on the relationships of selected Paleogene Myomorpha. Proceedings of the San Diego Society of Natural History, 32:1-20.

Walsh, S.L. 1998. Notes on the anterior dentition and skull of Proterixoides (Mammalia: Insectivora: Dormaaliidae), and a new dormaaliid genus from the early Uintan (middle Eocene) of southern California. Proceedings of the San Diego Society of Natural History, 34:1-26.

Walsh, S.L. 2000. Bunodont artiodactyls (Mammalia) from the Uintan (middle Eocene) of San Diego County, California. Proceedings of the San Diego Society of Natural History, 37:1-27.

Walsh, S.L and Estes, R. 1985. Earlier Eocene? Microvertebrate fossils from San Diego County, California: A preliminary report, p. 75-83. In Abbott, P.L. (ed.), On the Manner of Deposition of the Eocene Strata in Northern San Diego County. San Diego Association of Geologists field trip guide book.

Walsh, S.L. and Gutzler, R.Q. 1999. Late Duchesnean-early Chadronian mammals from the upper member of the Pomerado Conglomerate, San Diego, California. Journal of Vertebrate Paleontology, 19:82A (abstract). 
Walsh, S.L., Prothero, D.R., and Lundquist, D.J. 1996. Stratigraphy and paleomagnetism of the middle Eocene Friars Formation and Poway Group in southwestern San Diego County, California, p. 120-154. In Prothero, D.R. and Emry R.J. (eds.), The Terrestrial EoceneOligocene Transition in North America. Cambridge University Press, Cambridge.

Wesley, G.D. and Flynn, J.J. 2003. A revision of Tapocyon (Carnivoramorpha), including analysis of the first cranial specimens and identification of a new species. Journal of Paleontology, 77:796-783. https://doi.org/10.1666/0022-3360(2003)077<0769:AROTCI>2.0.CO;2

West, R.M. 1976. Paleontology and geology of the Bridger Formation, southern Green River Basin, southwestern Wyoming. Part 7. Survey of Bridgerian Artiodactyla, including description of a skull and partial skeleton of Antiacodon pygmaeus. Contributions to Biology and Geology, 56:1-47.

West, R.M. and Dawson, M.R. 1977. Mammals from the Palaeogene of the Eureka Sound Formation: Ellesmere Island, Arctic Canada. Géobios, Mémoire spécial, 1:107-124. https:// doi.org/10.1016/S0016-6995(77)80011-9

Williams, B.A. 1994. Phylogeny of the Omomyidae and implications for anthropoid origins. Unpublished Ph.D. thesis, University of Colorado, Boulder, Colorado, USA.

Williams, B.A. and Covert, H.H. 1994. New early Eocene Anaptomorphine primate (Omomyidae) from the Washakie Basin, Wyoming, with comments on the phylogeny and paleobiology of anaptomorphines. American Journal of Physical Anthropology, 93:323-340. https://doi.org/ 10.1002/ajpa.1330930305

Wilson, R.W. 1935a. Cricetine-like rodents from the Sespe Eocene of California. Proceedings of the National Academy of Sciences of the United States of America, 21:26-32. https://doi.org/ 10.1073/pnas.21.1.26

Wilson, R.W. 1935b. Simimys, a new name to replace Eumysops Wilson, preoccupied -A correction. Proceedings of the National Academy of Science of the United States of America, 21:179-180.

Wilson, R.W. 1940a. Californian paramyid rodents. Carnegie Institution of Washington Publication, 514:59-83.

Wilson, R.W. 1940b. Two new Eocene rodents from California. Carnegie Institution of Washington Publication, 514:85-95.

Zachos, J.C., Dickens, G.R., and Zeebe, R.E. 2008. An early Cenozoic perspective on greenhouse warming and carbon-cycle dynamics. Nature, 45:279-283. https://doi.org/ 10.1038/nature06588 


\section{APPENDIX 1.}

APPENDIX TABLE 1. Measurements (in $\mathrm{mm}$ ) for upper molars of Trogolemurini.

\begin{tabular}{|c|c|c|c|c|c|c|c|c|c|c|}
\hline Specimen & Species & M1L & M1W & M2L & M2W & M3L & M3W & Locality & Reference & Notes \\
\hline CM 14598 & $\begin{array}{l}\text { Walshina } \\
\text { shifrae comb. } \\
\text { nov. }\end{array}$ & - & - & 1.24 & 1.81 & - & - & $\begin{array}{l}\text { 5(A?), Badwater Creek, } \\
\text { Natrona Co, WY, USA }\end{array}$ & $\begin{array}{l}\text { Robinson } \\
(1968)\end{array}$ & $\begin{array}{l}\text { Identified as } \\
\text { lgnacius } \\
\text { mcgrewi in } \\
\text { Robinson (1986) }\end{array}$ \\
\hline CM 15103 & $\begin{array}{l}\text { Walshina } \\
\text { shifrae comb. } \\
\text { nov. }\end{array}$ & - & - & 1.40 & 2.00 & - & - & $\begin{array}{l}\text { Badwater Creek, Natrona } \\
\text { Co, WY, USA }\end{array}$ & $\begin{array}{l}\text { Krishtalka } \\
(1978)\end{array}$ & \\
\hline CM 15635 & $\begin{array}{l}\text { Walshina } \\
\text { mcgrewi comb. } \\
\text { nov. }\end{array}$ & 2.00 & 2.78 & - & - & - & - & $\begin{array}{l}\text { 5-front, Badwater Creek, } \\
\text { Natrona Co, WY, USA }\end{array}$ & $\begin{array}{l}\text { Robinson } \\
\text { (1968) }\end{array}$ & Holotype \\
\hline CM 15794 & $\begin{array}{l}\text { Walshina } \\
\text { mcgrewi comb. } \\
\text { nov. }\end{array}$ & - & - & 1.80 & 2.90 & - & - & $\begin{array}{l}\text { Badwater Creek, Natrona } \\
\text { Co, WY, USA }\end{array}$ & $\begin{array}{l}\text { Krishtalka } \\
(1978)\end{array}$ & \\
\hline CM 15795 & $\begin{array}{l}\text { Walshina } \\
\text { mcgrewi comb. } \\
\text { nov. }\end{array}$ & 2.00 & - & - & - & - & - & $\begin{array}{l}\text { Badwater Creek, Natrona } \\
\text { Co, WY, USA }\end{array}$ & $\begin{array}{l}\text { Krishtalka } \\
(1978)\end{array}$ & \\
\hline CM 15796 & $\begin{array}{l}\text { Walshina } \\
\text { mcgrewi comb. } \\
\text { nov. }\end{array}$ & 2.00 & - & - & - & - & - & $\begin{array}{l}\text { Badwater Creek, Natrona } \\
\text { Co, WY, USA }\end{array}$ & $\begin{array}{l}\text { Krishtalka } \\
(1978)\end{array}$ & \\
\hline CM 15797 & $\begin{array}{l}\text { Walshina } \\
\text { shifrae comb. } \\
\text { nov. }\end{array}$ & 1.30 & 2.00 & - & - & - & - & $\begin{array}{l}\text { Badwater Creek, Natrona } \\
\text { Co, WY, USA }\end{array}$ & $\begin{array}{l}\text { Krishtalka } \\
(1978)\end{array}$ & Holotype \\
\hline CM 15798 & $\begin{array}{l}\text { Walshina } \\
\text { shifrae comb. } \\
\text { nov. }\end{array}$ & - & - & 1.40 & - & - & - & $\begin{array}{l}\text { Badwater Creek, Natrona } \\
\text { Co, WY, USA }\end{array}$ & $\begin{array}{l}\text { Krishtalka } \\
(1978)\end{array}$ & \\
\hline CM 15799 & $\begin{array}{l}\text { Walshina } \\
\text { shifrae comb. } \\
\text { nov. }\end{array}$ & 1.20 & 1.90 & - & - & - & - & $\begin{array}{l}\text { Badwater Creek, Natrona } \\
\text { Co, WY, USA }\end{array}$ & $\begin{array}{l}\text { Krishtalka } \\
(1978)\end{array}$ & \\
\hline LACM 40198 & $\begin{array}{l}\text { Walshina } \\
\text { esmaraldensis } \\
\text { gen. et sp. nov. }\end{array}$ & 1.60 & 2.20 & - & - & - & - & $\begin{array}{l}\text { LACM }(\mathrm{CIT}) 180 \text {, north of } \\
\text { Simi Valley, Ventura Co, } \\
\text { CA, USA }\end{array}$ & This paper & Holotype \\
\hline $\begin{array}{l}\text { SDNHM } \\
42268\end{array}$ & $\begin{array}{l}\text { Walshina } \\
\text { esmaraldensis } \\
\text { gen. et sp. nov. }\end{array}$ & - & - & 1.66 & - & - & - & $\begin{array}{l}\text { SDNHM loc. } 3426 \text {, } \\
\text { Collwood South, San } \\
\text { Diego Co, CA, USA }\end{array}$ & This paper & \\
\hline $\begin{array}{l}\text { SDNHM } \\
62850\end{array}$ & $\begin{array}{l}\text { Walshina } \\
\text { esmaraldensis } \\
\text { gen. et sp. nov. }\end{array}$ & - & - & 1.64 & 2.39 & - & - & $\begin{array}{l}\text { SDNHM loc. } 4020 \text {, State } \\
\text { Route 125, San Diego Co, } \\
\text { CA, USA }\end{array}$ & This paper & \\
\hline $\begin{array}{l}\text { SDNHM } \\
76267\end{array}$ & $\begin{array}{l}\text { Walshina } \\
\text { esmaraldensis } \\
\text { gen. et sp. nov. }\end{array}$ & - & - & - & - & 1.31 & 2.05 & $\begin{array}{l}\text { SDNHM loc. } 4082 \\
\text { (Emerald Ridge 2), } \\
\text { northwest San Diego Co, } \\
\text { CA, USA }\end{array}$ & This paper & \\
\hline $\begin{array}{l}\text { SDNHM } \\
87336\end{array}$ & $\begin{array}{l}\text { Walshina } \\
\text { esmaraldensis } \\
\text { gen. et sp. nov. }\end{array}$ & - & - & 1.76 & 2.48 & - & - & $\begin{array}{l}\text { SDNHM loc. 4925, Kelly } \\
\text { Ranch Core, San Diego } \\
\text { Co, CA, USA }\end{array}$ & This paper & \\
\hline $\begin{array}{l}\text { SDNHM } \\
87337\end{array}$ & $\begin{array}{l}\text { Walshina } \\
\text { esmaraldensis } \\
\text { gen. et sp. nov. }\end{array}$ & - & - & 1.54 & - & - & - & $\begin{array}{l}\text { SDNHM loc. 4925, Kelly } \\
\text { Ranch Core, San Diego } \\
\text { Co, CA, USA }\end{array}$ & This paper & \\
\hline $\begin{array}{l}\text { SMNH } \\
\text { P1899.1007 }\end{array}$ & $\begin{array}{l}\text { Trogolemur } \\
\text { leonardi }\end{array}$ & 1.90 & 3.17 & - & - & - & - & $\begin{array}{l}\text { SMNH loc. 72J04-0006, } \\
\text { east side of Lac Pelletier, } \\
\text { SK, Canada }\end{array}$ & $\begin{array}{l}\text { Storer } \\
(1990)\end{array}$ & \\
\hline $\begin{array}{l}\text { SMNH } \\
\text { P1899.1016 }\end{array}$ & $\begin{array}{l}\text { Trogolemur } \\
\text { leonardi }\end{array}$ & - & - & - & - & 1.58 & 2.57 & $\begin{array}{l}\text { SMNH loc. 72J04-0006, } \\
\text { east side of Lac Pelletier, } \\
\text { SK, Canada }\end{array}$ & $\begin{array}{l}\text { Storer } \\
(1990)\end{array}$ & $\begin{array}{l}\text { Identified as M2 } \\
\text { in Storer (1990) }\end{array}$ \\
\hline
\end{tabular}


PALAEO-ELECTRONICA.ORG

\begin{tabular}{|c|c|c|c|c|c|c|c|c|c|c|}
\hline Specimen & Species & M1L & M1W & M2L & M2W & M3L & M3W & Locality & Reference & Notes \\
\hline UCM 25049 & $\begin{array}{l}\text { Walshina } \\
\text { shifrae comb. } \\
\text { nov. }\end{array}$ & - & - & 1.24 & 1.67 & - & - & $\begin{array}{l}\text { 5A, Badwater Creek, } \\
\text { Natrona Co, WY, USA }\end{array}$ & $\begin{array}{l}\text { Robinson } \\
(1968)\end{array}$ & $\begin{array}{l}\text { Identified as } \\
\text { Ignacius } \\
\text { mcgrewi in } \\
\text { Robinson (1986) }\end{array}$ \\
\hline $\begin{array}{l}\text { USNM } \\
417390\end{array}$ & $\begin{array}{l}\text { Trogolemur } \\
\text { myodes }\end{array}$ & - & - & 1.60 & 2.60 & - & - & $\begin{array}{l}\text { Elderberry Canyon } \\
\text { Quarry, White Pine Co, } \\
\text { NE, USA }\end{array}$ & $\begin{array}{l}\text { Emry } \\
(1990)\end{array}$ & \\
\hline $\begin{array}{l}\text { USNM } \\
417391\end{array}$ & $\begin{array}{l}\text { Trogolemur } \\
\text { myodes }\end{array}$ & - & - & - & - & 1.30 & 2.20 & $\begin{array}{l}\text { Elderberry Canyon } \\
\text { Quarry, White Pine Co, } \\
\text { NE, USA }\end{array}$ & $\begin{array}{l}\text { Emry } \\
(1990)\end{array}$ & $\begin{array}{l}\text { Incorrectly listed } \\
\text { as a lower m3 in } \\
\text { Emry (1990) }\end{array}$ \\
\hline $\begin{array}{l}\text { USNM } \\
417396\end{array}$ & $\begin{array}{l}\text { Trogolemur } \\
\text { myodes }\end{array}$ & 1.60 & 2.30 & - & - & - & - & $\begin{array}{l}\text { Elderberry Canyon } \\
\text { Quarry, White Pine Co, } \\
\text { NE, USA }\end{array}$ & $\begin{array}{l}\text { Emry } \\
(1990)\end{array}$ & $\begin{array}{l}\text { Identified as M2 } \\
\text { in Emry (1990) }\end{array}$ \\
\hline
\end{tabular}


APPENDIX TABLE 2. Measurements (in $\mathrm{mm}$ ) for lower dentition of Trogolemurini.

\begin{tabular}{|c|c|c|c|c|c|c|c|c|c|c|c|c|c|}
\hline 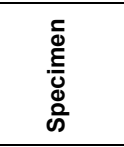 & 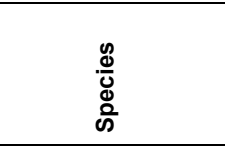 & ભૂ & 令 & $\underset{z}{2}$ & 羡 & $\vec{\xi}$ & $\frac{3}{\xi}$ & สู & సె & ભ & కై & 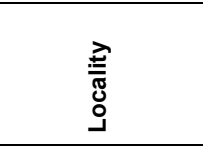 & 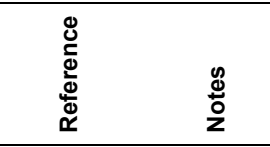 \\
\hline $\begin{array}{l}\text { AMNH } \\
12599\end{array}$ & $\begin{array}{l}\text { Trogolemur } \\
\text { myodes }\end{array}$ & 1.05 & 0.78 & 1.33 & 1.14 & 1.66 & 1.23 & 1.60 & 1.44 & 2.07 & 1.27 & $\begin{array}{l}\text { Granger S 6, } \\
\text { Uinta Co, WY, } \\
\text { USA }\end{array}$ & This paper Holotype \\
\hline $\begin{array}{l}\text { CM } \\
15793\end{array}$ & $\begin{array}{l}\text { Walshina } \\
\text { mcgrewi comb. } \\
\text { nov. }\end{array}$ & - & - & - & - & - & - & 2.00 & 1.80 & - & - & $\begin{array}{l}\text { Badwater } \\
\text { Creek, Natrona } \\
\text { Co, WY, USA }\end{array}$ & $\begin{array}{l}\text { Krishtalka } \\
\text { (1978) }\end{array}$ \\
\hline $\begin{array}{l}\text { CM } \\
21637\end{array}$ & $\begin{array}{l}\text { Walshina shifrae } \\
\text { comb. nov. }\end{array}$ & - & - & - & - & - & - & 1.50 & 1.30 & - & - & $\begin{array}{l}\text { Badwater } \\
\text { Creek, Natrona } \\
\text { Co, WY, USA }\end{array}$ & $\begin{array}{l}\text { Krishtalka } \\
(1978)\end{array}$ \\
\hline $\begin{array}{l}\text { CM } \\
40069\end{array}$ & $\begin{array}{l}\text { Trogolemur } \\
\text { amplior }\end{array}$ & - & - & - & - & 2.20 & 1.85 & 1.95 & 1.95 & - & - & $\begin{array}{l}\text { CM loc. 34, } \\
\text { Wind River } \\
\text { Basin, Natrona } \\
\text { Co, WY, USA }\end{array}$ & $\begin{array}{l}\text { Beard et } \\
\text { al. (1992) }\end{array}$ \\
\hline $\begin{array}{l}\text { CM } \\
41152\end{array}$ & $\begin{array}{l}\text { Trogolemur } \\
\text { fragilis }\end{array}$ & - & - & - & - & - & - & - & - & 1.95 & 1.20 & $\begin{array}{l}\text { CM loc. } 34 \text {, } \\
\text { Wind River } \\
\text { Basin, Natrona } \\
\text { Co, WY, USA }\end{array}$ & $\begin{array}{l}\text { Beard et } \\
\text { al. (1992) }\end{array}$ \\
\hline $\begin{array}{l}\text { SDNHM } \\
72583\end{array}$ & $\begin{array}{l}\text { Walshina } \\
\text { esmaraldensis } \\
\text { gen. et sp. nov. }\end{array}$ & - & - & - & - & - & - & - & - & 1.80 & 1.18 & $\begin{array}{l}\text { SDNHM loc. } \\
4081 \text { (Emerald } \\
\text { Ridge 1), } \\
\text { northwest San } \\
\text { Diego Co, CA, } \\
\text { USA }\end{array}$ & This paper \\
\hline $\begin{array}{l}\text { SDNHM } \\
76266\end{array}$ & $\begin{array}{l}\text { Walshina } \\
\text { esmaraldensis } \\
\text { gen. et sp. nov. }\end{array}$ & - & - & - & - & - & - & - & - & 2.07 & 1.26 & $\begin{array}{l}\text { SDNHM loc. } \\
4082 \text { (Emerald } \\
\text { Ridge 2), } \\
\text { northwest San } \\
\text { Diego Co, CA, } \\
\text { USA }\end{array}$ & This paper \\
\hline $\begin{array}{l}\text { SDNHM } \\
76337\end{array}$ & $\begin{array}{l}\text { Walshina } \\
\text { esmaraldensis } \\
\text { gen. et sp. nov. }\end{array}$ & - & - & - & - & 1.83 & 1.48 & - & - & - & - & $\begin{array}{l}\text { SDNHM loc. } \\
4082 \text { (Emerald } \\
\text { Ridge 2), } \\
\text { northwest San } \\
\text { Diego Co, CA, } \\
\text { USA }\end{array}$ & This paper \\
\hline $\begin{array}{l}\text { SDNHM } \\
76338\end{array}$ & $\begin{array}{l}\text { Walshina } \\
\text { esmaraldensis } \\
\text { gen. et sp. nov. }\end{array}$ & - & - & - & - & - & - & 1.90 & 1.61 & - & - & & This paper \\
\hline $\begin{array}{l}\text { SDNHM } \\
76339\end{array}$ & $\begin{array}{l}\text { Walshina } \\
\text { esmaraldensis } \\
\text { gen. et sp. nov. }\end{array}$ & - & - & - & - & - & - & - & - & - & 1.19 & $\begin{array}{l}\text { SDNHM loc. } \\
4082 \text { (Emerald } \\
\text { Ridge 2), } \\
\text { northwest San } \\
\text { Diego Co, CA, } \\
\text { USA }\end{array}$ & This paper \\
\hline $\begin{array}{l}\text { SDNHM } \\
87332\end{array}$ & $\begin{array}{l}\text { Walshina } \\
\text { esmaraldensis } \\
\text { gen. et sp. nov. }\end{array}$ & - & - & - & - & - & - & 1.79 & 1.46 & - & - & $\begin{array}{l}\text { SDNHM loc. } \\
4925, \text { Kelly } \\
\text { Ranch Core, } \\
\text { San Diego Co, } \\
\text { CA, USA }\end{array}$ & This paper \\
\hline $\begin{array}{l}\text { SDNHM } \\
87333\end{array}$ & $\begin{array}{l}\text { Walshina } \\
\text { esmaraldensis } \\
\text { gen. et sp. nov. }\end{array}$ & - & - & - & - & - & - & 1.79 & 1.57 & - & - & $\begin{array}{l}\text { SDNHM loc. } \\
\text { 4925, Kelly } \\
\text { Ranch Core, } \\
\text { San Diego Co, } \\
\text { CA, USA }\end{array}$ & This paper \\
\hline
\end{tabular}




\begin{tabular}{|c|c|c|c|c|c|c|c|c|c|c|c|c|c|c|}
\hline 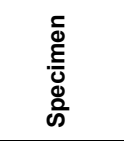 & $\begin{array}{l}\frac{\mathscr{c}}{0} \\
\frac{0}{0} \\
\text { की }\end{array}$ & ભ̆ & 袞 & $\stackrel{\vec{Z}}{\Omega}$ & 竞 & $\stackrel{\vec{E}}{\xi}$ & $\stackrel{3}{\xi}$ & สู & ฌิ & $\stackrel{\text { m }}{\xi}$ & 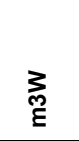 & $\frac{7}{\sqrt{\pi}}$ & 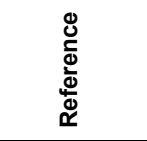 & 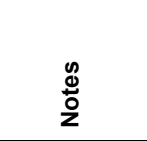 \\
\hline $\begin{array}{l}\text { SDNHM } \\
87334\end{array}$ & $\begin{array}{l}\text { Walshina } \\
\text { esmaraldensis } \\
\text { gen. et sp. nov. }\end{array}$ & - & - & - & - & - & - & - & - & 2.17 & 1.38 & $\begin{array}{l}\text { SDNHM loc. } \\
4925, \text { Kelly } \\
\text { Ranch Core, } \\
\text { San Diego Co, } \\
\text { CA, USA }\end{array}$ & This paper & \\
\hline $\begin{array}{l}\text { UCM } \\
25175\end{array}$ & $\begin{array}{l}\text { Walshina shifrae } \\
\text { comb. nov. }\end{array}$ & - & - & - & - & - & - & 1.50 & 1.33 & - & - & $\begin{array}{l}\text { 5A, Badwater } \\
\text { Creek, Natrona } \\
\text { Co, WY, USA }\end{array}$ & $\begin{array}{l}\text { Robinson } \\
(1968)\end{array}$ & $\begin{array}{l}\text { Identified } \\
\text { as } \\
\text { lgnacius } \\
\text { mogrewi in } \\
\text { Robinson } \\
\text { (1986) }\end{array}$ \\
\hline $\begin{array}{l}\text { UCM } \\
26012\end{array}$ & $\begin{array}{l}\text { Walshina } \\
\text { mcgrewi comb. } \\
\text { nov. }\end{array}$ & - & - & - & - & 2.06 & 1.76 & - & - & - & - & $\begin{array}{l}\text { 5A, Badwater } \\
\text { Creek, Natrona } \\
\text { Co, WY, USA }\end{array}$ & $\begin{array}{l}\text { Robinson } \\
(1968)\end{array}$ & \\
\hline $\begin{array}{l}\text { UCM } \\
26432\end{array}$ & $\begin{array}{l}\text { Walshina shifrae } \\
\text { comb. nov. }\end{array}$ & - & - & - & - & - & - & 1.25 & 1.06 & - & - & $\begin{array}{l}\text { 5A, Badwater } \\
\text { Creek, Natrona } \\
\text { Co, WY, USA }\end{array}$ & $\begin{array}{l}\text { Robinson } \\
(1968)\end{array}$ & $\begin{array}{l}\text { Identified } \\
\text { as } \\
\text { Ignacius } \\
\text { mcgrewi in } \\
\text { Robinson } \\
\text { (1986) }\end{array}$ \\
\hline $\begin{array}{l}\text { UCM } \\
29005\end{array}$ & $\begin{array}{l}\text { Walshina } \\
\text { mcgrewi comb. } \\
\text { nov. }\end{array}$ & - & - & - & - & - & - & 2.00 & 1.85 & - & - & $\begin{array}{l}\text { Badwater } \\
\text { Creek, Natrona } \\
\text { Co, WY, USA }\end{array}$ & $\begin{array}{l}\text { Krishtalka } \\
\text { (1978) }\end{array}$ & \\
\hline $\begin{array}{l}\text { UCM } \\
38323\end{array}$ & $\begin{array}{l}\text { Walshina shifrae } \\
\text { comb. nov. }\end{array}$ & - & - & - & - & - & - & 1.40 & 1.30 & - & - & $\begin{array}{l}\text { Badwater } \\
\text { Creek, Natrona } \\
\text { Co, WY, USA }\end{array}$ & $\begin{array}{l}\text { Krishtalka } \\
(1978)\end{array}$ & \\
\hline $\begin{array}{l}\text { UCM } \\
46602\end{array}$ & $\begin{array}{l}\text { Trogolemur } \\
\text { amplior }\end{array}$ & 1.20 & 0.95 & - & - & - & - & - & - & - & - & $\begin{array}{l}\text { UCM loc. } \\
80062 \text {, Wind } \\
\text { River Basin, } \\
\text { Natrona Co, } \\
\text { WY, USA }\end{array}$ & $\begin{array}{l}\text { Beard et } \\
\text { al. }(1992)\end{array}$ & \\
\hline $\begin{array}{l}\text { UM } \\
30966\end{array}$ & $\begin{array}{l}\text { Sphacorhysis } \\
\text { burntforkensis }\end{array}$ & - & - & 1.40 & 1.30 & 1.90 & 1.50 & 2.00 & 1.80 & 1.80 & 1.50 & $\begin{array}{l}\text { UM loc. BRW- } \\
264, \text { sec. } 22, \\
\text { T.13N., } \\
\text { R.113W., Uinta } \\
\text { Co, WY, USA }\end{array}$ & $\begin{array}{l}\text { Gunnell } \\
\text { (1995) }\end{array}$ & \\
\hline $\begin{array}{l}\text { USNM } \\
417355\end{array}$ & $\begin{array}{l}\text { Trogolemur } \\
\text { myodes }\end{array}$ & 1.00 & 0.80 & 1.20 & 1.20 & 1.70 & 1.50 & 1.40 & 1.60 & 2.00 & 1.30 & $\begin{array}{l}\text { Elderberry } \\
\text { Canyon } \\
\text { Quarry, White } \\
\text { Pine Co, NE, } \\
\text { USA }\end{array}$ & $\begin{array}{l}\text { Emry } \\
(1990)\end{array}$ & \\
\hline $\begin{array}{l}\text { USNM } \\
417356\end{array}$ & $\begin{array}{l}\text { Trogolemur } \\
\text { myodes }\end{array}$ & 1.00 & 0.90 & 1.10 & 1.25 & 1.50 & 1.50 & 1.40 & 1.60 & 2.10 & 1.40 & $\begin{array}{l}\text { Elderberry } \\
\text { Canyon } \\
\text { Quarry, White } \\
\text { Pine Co, NE, } \\
\text { USA }\end{array}$ & $\begin{array}{l}\text { Emry } \\
(1990)\end{array}$ & \\
\hline $\begin{array}{l}\text { USNM } \\
417389\end{array}$ & $\begin{array}{l}\text { Trogolemur } \\
\text { myodes }\end{array}$ & - & - & - & - & 1.70 & 1.50 & - & - & - & - & $\begin{array}{l}\text { Elderberry } \\
\text { Canyon } \\
\text { Quarry, White } \\
\text { Pine Co, NE, } \\
\text { USA }\end{array}$ & $\begin{array}{l}\text { Emry } \\
(1990)\end{array}$ & \\
\hline $\begin{array}{l}\text { YPM VP } \\
13523\end{array}$ & $\begin{array}{l}\text { Trogolemur } \\
\text { myodes }\end{array}$ & - & - & - & - & - & - & 1.41 & 1.43 & 1.96 & 1.15 & $\begin{array}{l}\text { Sweetwater } \\
\text { Co, WY, USA }\end{array}$ & This paper & \\
\hline
\end{tabular}




\section{APPENDIX 2.}

Newick format for tree from Figure 7.

(Scandentia,(Purgatorius_spp,((Altanius_orlovi,(Plesiolestes_problematicus,('Plesiadapis/Pronothodectes',Chronolestes_simul))),(Donrussellia_sp.,(((Lemur_catta,(Galagoides_demidoff,Mic rocebus_murinus)),((Mahgarita_stevensi,Rooneyia_viejaensis),(Notharctus_sp.,(Pronycticebus _gaudryi,(Adapis_parisiensis,Leptadapis_magnus))))),(Teilhardina_americana,(Teilhardina_belg ica,Teilhardina_asiatica),(Steinius_vespertinus,(Omomys_sp.,(Hemiacodon_gracilis,Macrotarsiu s_montanus))),(Eosimias_sp.,(Tarsius_sp.,(Proteopithecus_sylviae,(Catopithecus_browni,((Aeg yptopithecus_zeuxis,(Apidium_phiomense,Parapithecus_grangeri)),(Dolichocebus_gaimanensi s,(Callicebus_moloch,(Aotus_trivirgatus,Saimiri_sciureus $)))))))),((($ Uintanius_ameghini,(Tetonius sp.,((Absarokius_sp.,Anaptomorphus_sp.),(Aycrossia_lovei,Strigorhysis_sp. $)))),($ Loveina_shea i,Loveina_minuta,Loveina_wapitiensis,(Dyseolemur_pacificus,Washakius_insignis,Loveina_zep hyri,Shoshonius_cooperi))),((Nannopithex_sp.,Melaneremia_bryanti,Pseudoloris_parvulus,(Micr ochoerus_erinaceus,Necrolemur_antiquus)),((Anemorhysis_savagei,(Anemorhysis_wortmani,(( Anemorhysis_sublettensis,Anemorhysis_natronensis),(Arapahovius_gazini,Tetonoides_sp.)))),( Trogolemur_myodes,Trogolemur_amplior,Trogolemur_fragilis,Trogolemur_leonardi,Sphacorhysi s_burntforkensis,(Walshina_esmaraldensis,Walshina_mcgrewi,Walshina_shifrae))))))))))); 